QIJIS: Qudus International Journal of Islamic Studies Volume 5. Issue 2. August 2017

\title{
تأسيس مقاصد الثريعة التقدمية لرد الفكر الإرهابي والتطرفي (دراسة تحليلية أصولية)
}

\author{
نووي \\ بالجامعة الإبراهيمية الإسلاميةسيتوبوندو - جاوى الشرقية إندونيسيا \\ nawawithabrani71@gmail.com
}

ملخص

يقوم هذا البحث على إظهار تأسيس مقاصد الشريعة التقدمية لرد الفكر الإرهابي

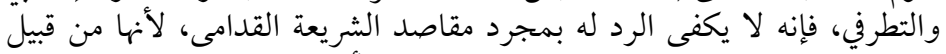

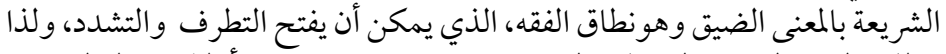

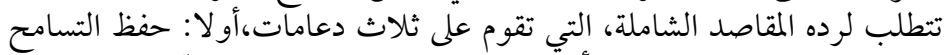

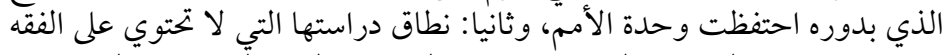

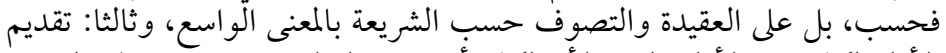

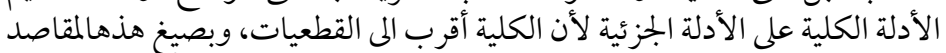

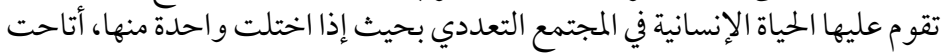
إمكانية الفكر الإرهابي و التطرفي.

الكلمات المفتاح: مقاصد الثريعة, التقدمية لرد الفكر , دراسة تحليلية أصولية

أ. أ. مقدمة

إن الإسلام بأبعاده الأفقية والرأسية قادرٌ على عمل توافُق قويٍ بين الإنسان والكون المحيط به، وكذلك بين الإنسان و الله خالقِ كل شيء و ومبدعِه، إن الإسلام عالمي بكل معنى الكلمة(عبدالوهاب، 1999: صعيدأخر، وكانالإرهاب أخطر ظاهرة وأسوأها في الخيات الاجتمعيات الإنسانية المعاصرة خطر اعظيما لم يسبق له مثيل، لأنه يستخدم أساليب متدينة 
خصوصا دين الإسلام، وأدوات غير مشروعة للوصول المى أهداف، ويعتبر من

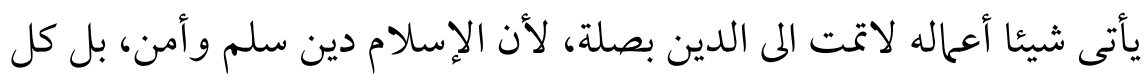
عمل ارهابي جريمة فى حق الله ورسوله، ومخالفا جوهر الشريعة الإسلامية.

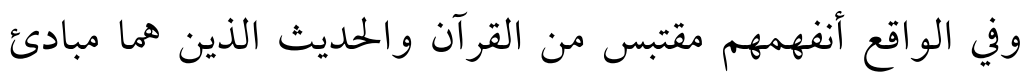

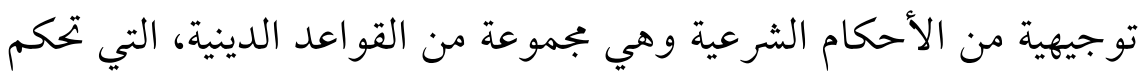

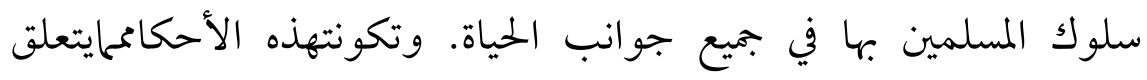

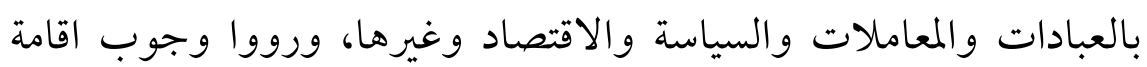

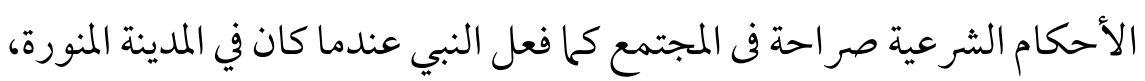

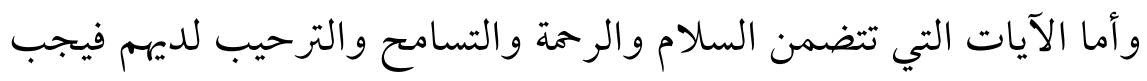
النسخ منهابآية واحدة وهي أية السيف أو آلقنل.

وإنه لامفر من التسليم بأن حركتهم أسوء خطيرا عظيها، لانهم

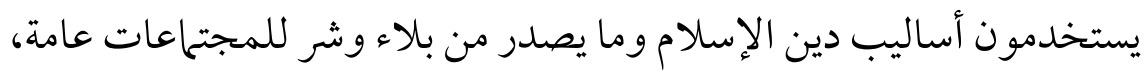

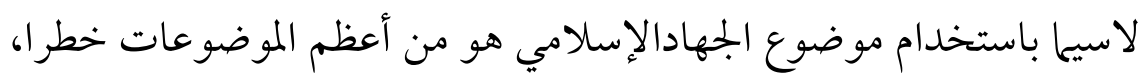

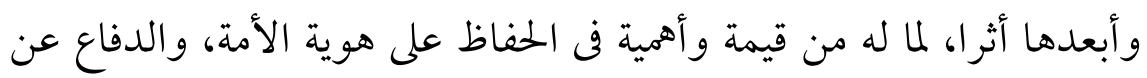

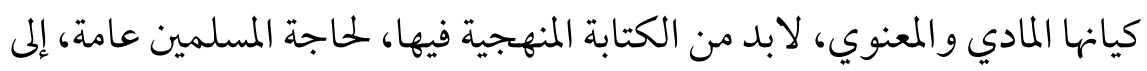

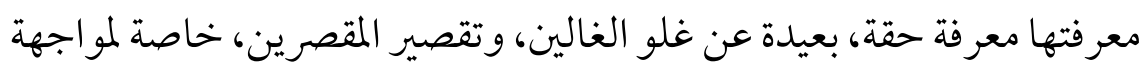

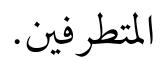

ومن ذلك الوصف ان أراءهم كانت خطيرة، تؤدي الى الحركات

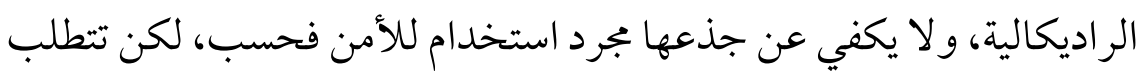

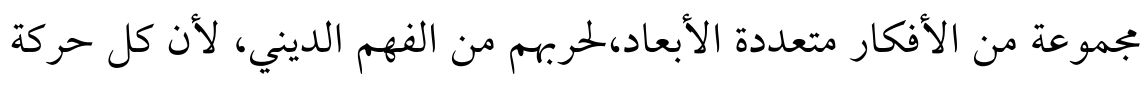

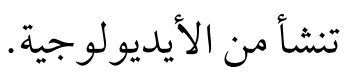




\section{ب. مقاصد الشريعة التقدميةلرد الفكر الإرهابي والتطرفي}

وإن لبروز الإرهاب في مجتمع ما دوافع عديدة، منها ماهو ديني، فأما

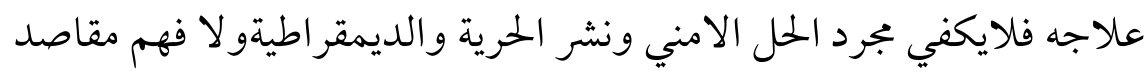

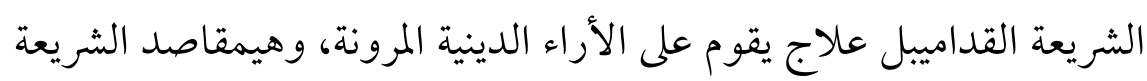

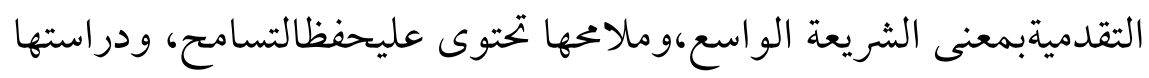

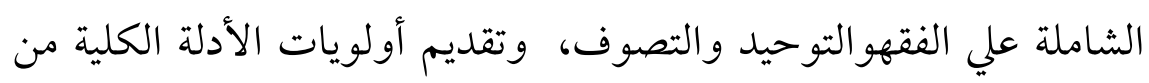

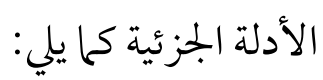

\section{أولا: حفظ التسامح}

إن مظاهر الغلو والتطرف فى واقعنا كثيرة كما أن بجلات التسامح

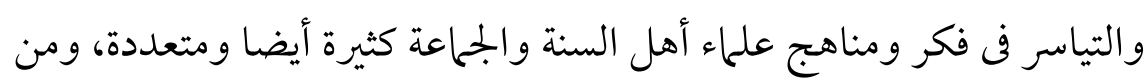

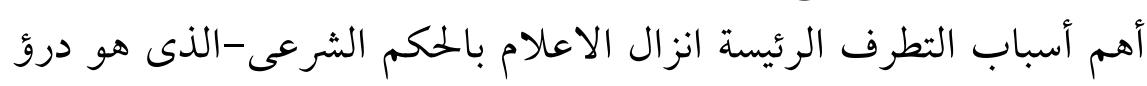

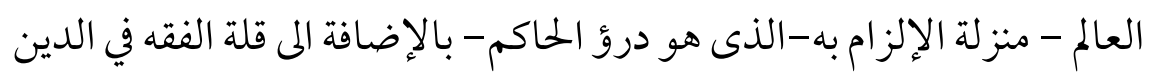
وعدم النضج العقلى بلايترتب عليه تكفير ولي الأمر ثم تكفير الرعية لاستحلال

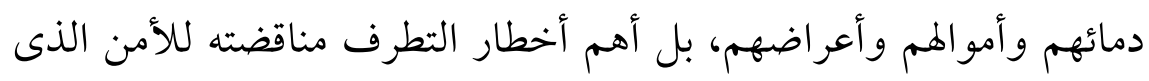

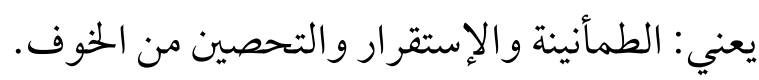

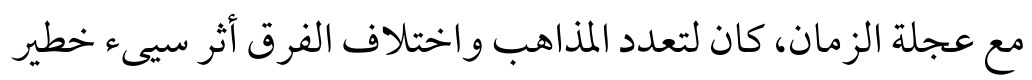

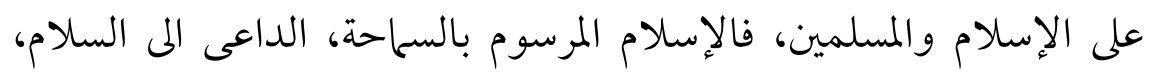

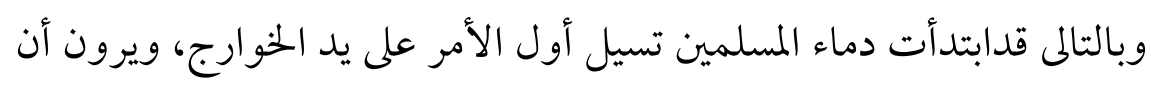

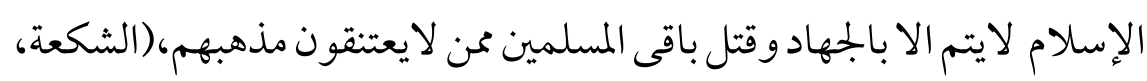

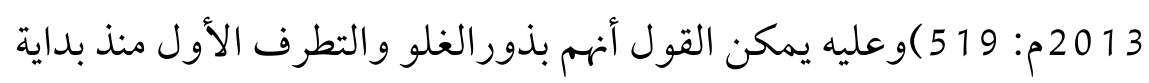
تاريخ الإسلام.

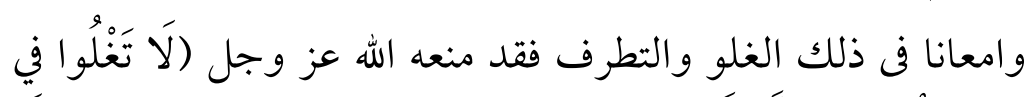

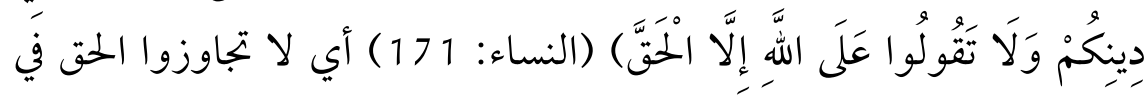


دينكم فتفرطو ا فيه. و أصل "( الغلو (، في كل شيء جاوزة حده الذي هو حدّه. يقال منه في الدين: " قد غلا فهو يغلو غلوَّا ((كذلك تحدثت السنة المشرفة

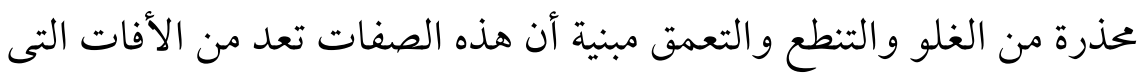
تفتك بالأفر اد والمجتماعات.

ولذا تتطلب مقاصد الشريعة، التى تستدعى ضرورة وحدة الأمة،وهى

حفظ التسامح،فالخروج عن إطار حفظ التسامح يؤدى الى الوقوع فى أوحال التنازع والتقاطع والتشرم، وقال الريسوني: "اوبعض المصالح الضرورة التي

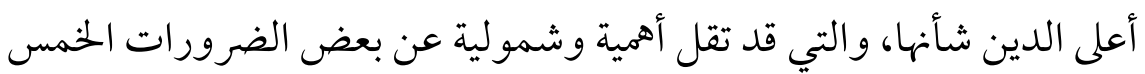

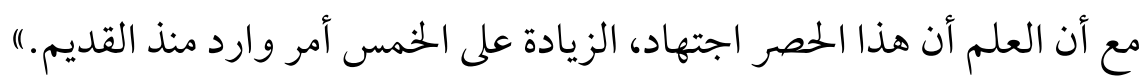
(الريسوني، 1992 م: 1414 ).

ومن المعلوم فى القرأن الكريم أن الأصل فى هذه الأمة وسائر الأمم الوحدة، وقد أمر الله عز وجل الإعتصام بحبل الله الجِامعأمراجازما وهو

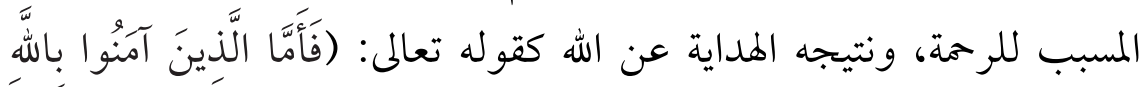

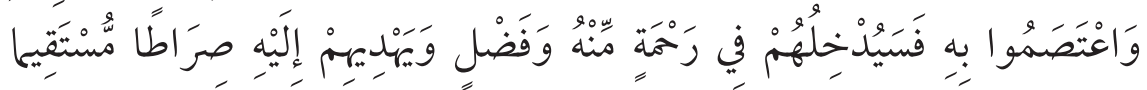

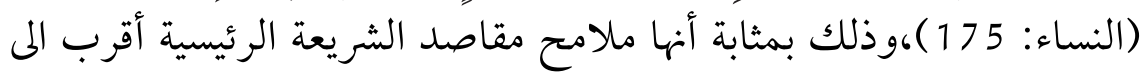
القطعيات.

وفى المقابل نجد أن الإرهابيين يخرجون على الشرع الإلهي، ويستبيحون

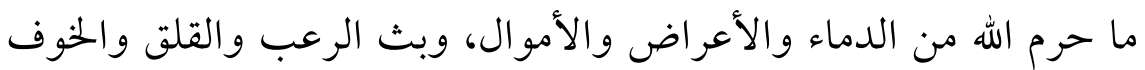
على ما لايجوز عرفا وشرعا- هو المحاربة والبغي، لا يصدر الا من فئة باغية، أوجماعة خارجة عن اجماع الأمة بتشددها وتطرفها و الغائها الحقوق الإنسانية في الحياة الامنة وحرية التدين،و أن المتطرفين هم الذين قديبلغ بهم الحماس و الغرور بـاس

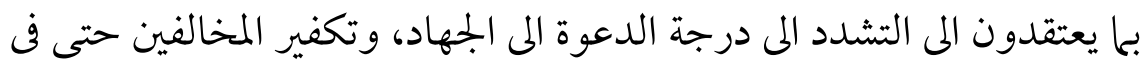

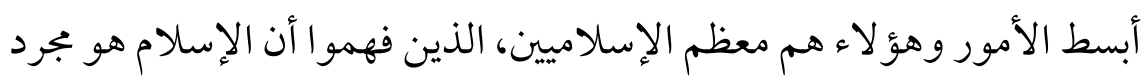


التزام الأحكام الشرعية، وتتولى تنفيذها سلطة تقوم بإسم الإسلام، وهذا لب الين و التدين عنهم. (الاحمام الترع.

وبالنظر الى أراء المتطرفين من التدين، يتضح لنا أنهم لايقومون على النى

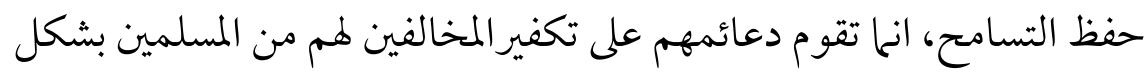

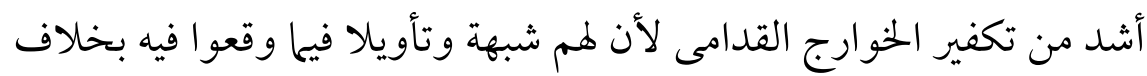

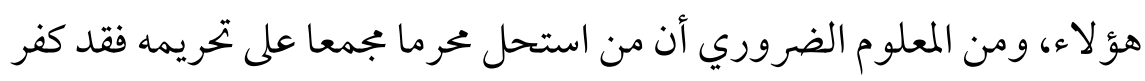

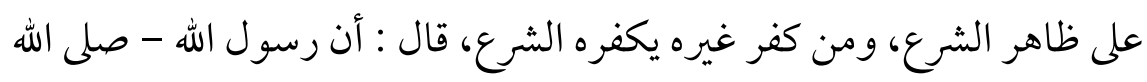

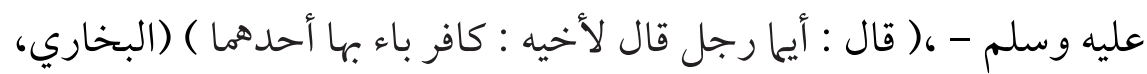
(2.ت: 6104)

ومما ينبغى ان نهتم به مزيد من الضروريات الخمسة هى حفظ التسامح

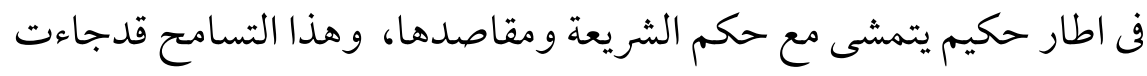

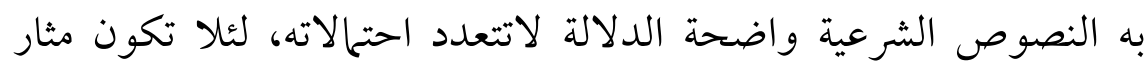

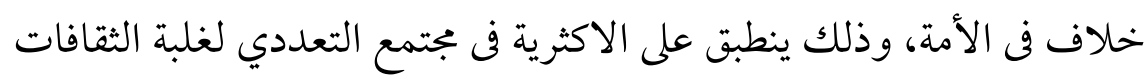

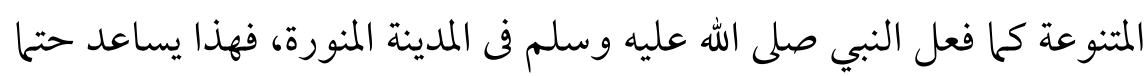
على مكافحة الإرهاب و التطرف. ولاشك أن أدلة حفظ التسامح من النصوفروف الشرعية كثيرة

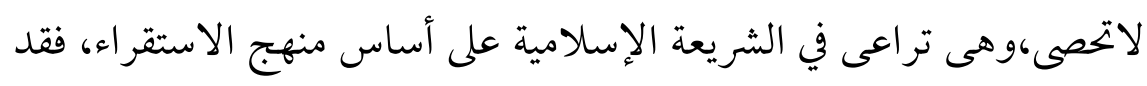

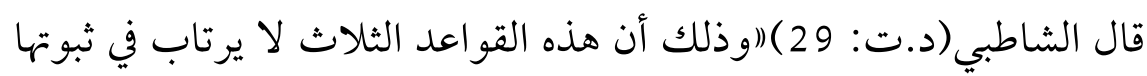

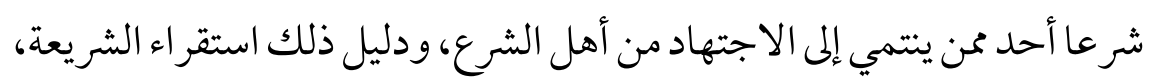

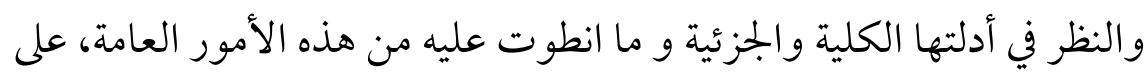

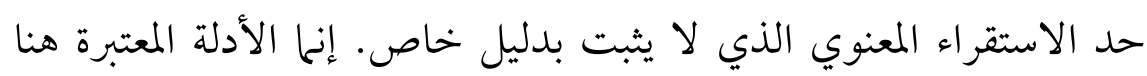

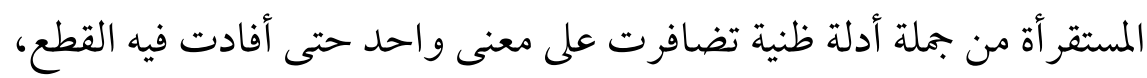

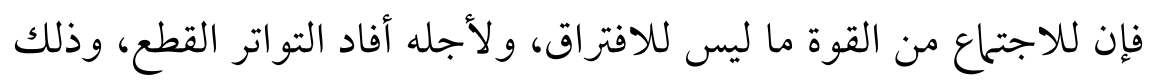


يتفق وماقاله الشيخ زكريا الأنصارى:)ان أدلة النقلية قد تفيد اليقين بانضمام

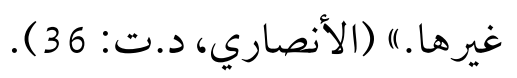

يدلنا استقراء نصوص الشريعة على أنها عنيت بتحقيق التواصل

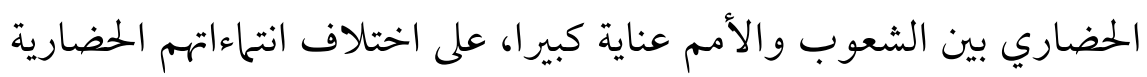

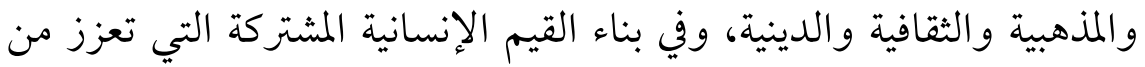

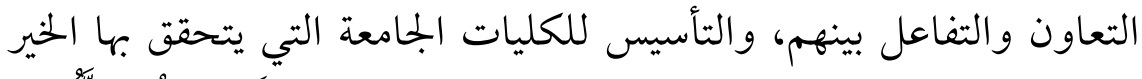

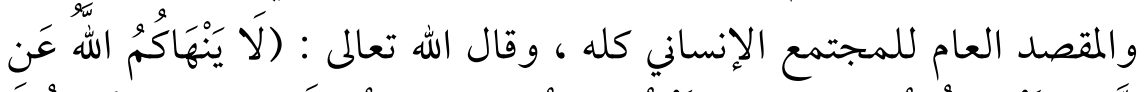

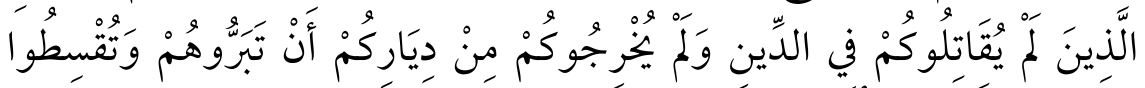

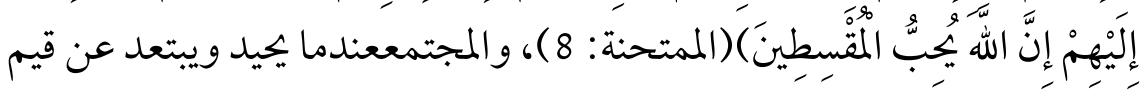

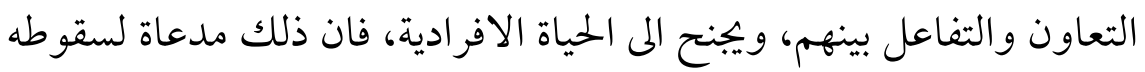
وانهياره، فقد كان ذلك يدمر المقاصد الشرعية القصوى.

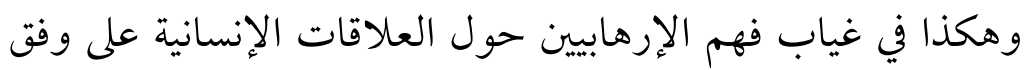

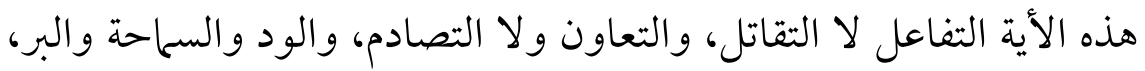

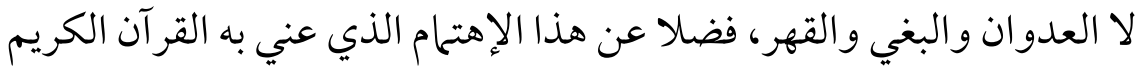

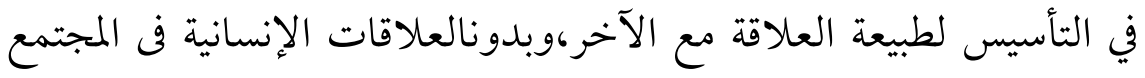

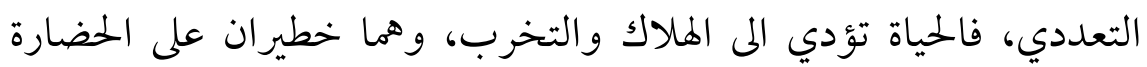

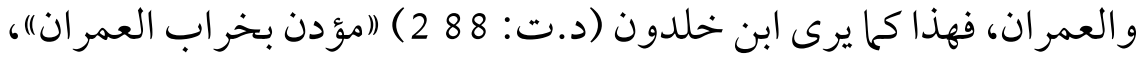

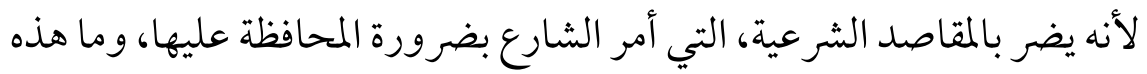

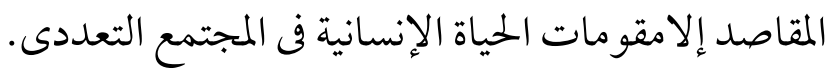
وكان من الطبيعي أن تلك العلاقات الإنسانيةلاتتحقق إلابحفظ

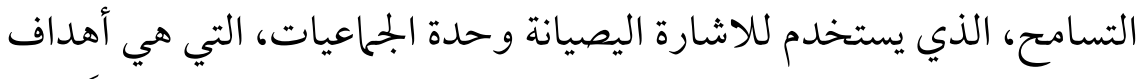

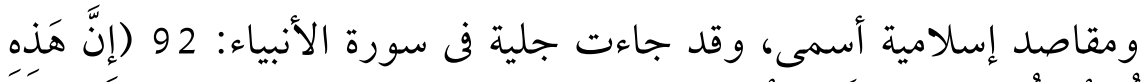

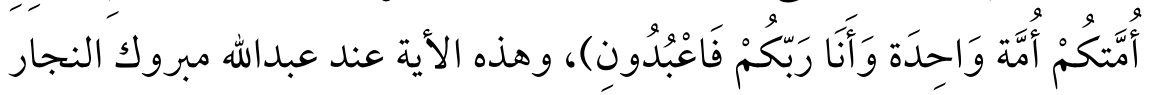

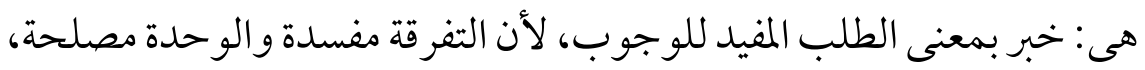


فهى بدل التفرقة وهى حرام، ومايمنع الحرام يكون واجبا (النجار، 2014م:

وعلى كل حال، لقد شهد العديد دونما شك من المفكرين غيرالمسلمين

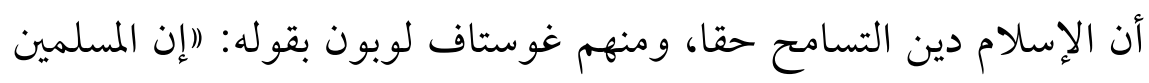

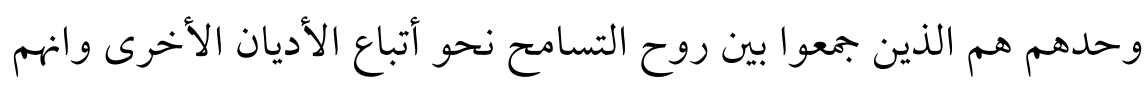

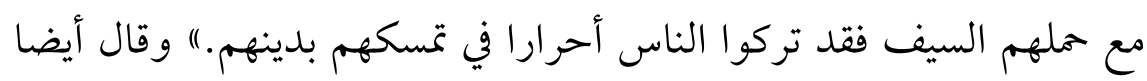

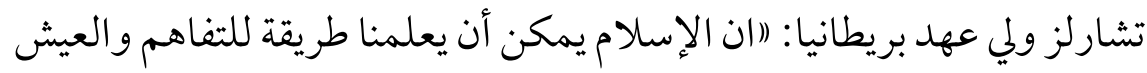

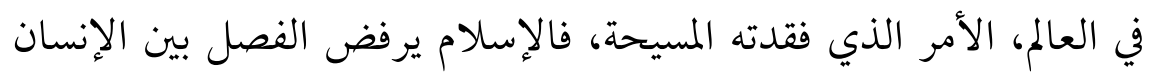

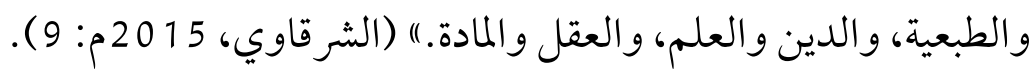

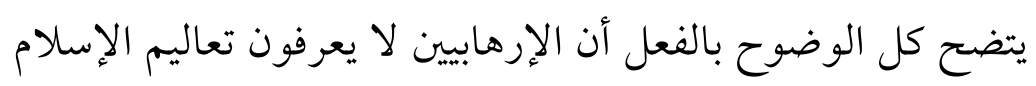

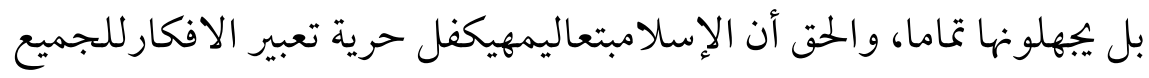

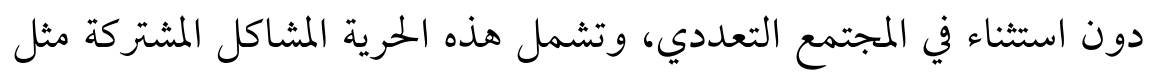

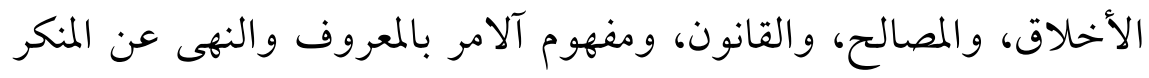

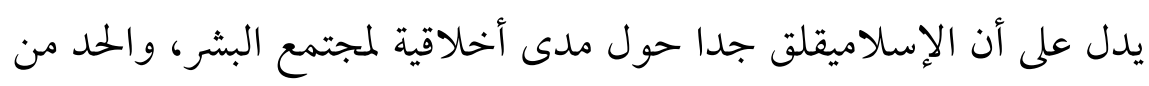

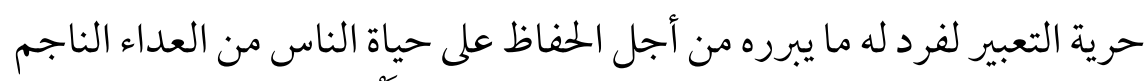

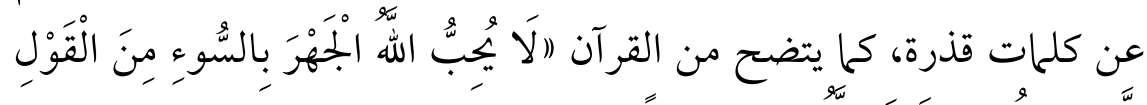

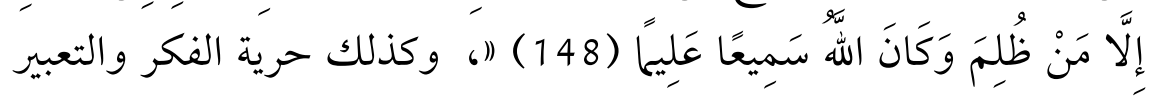

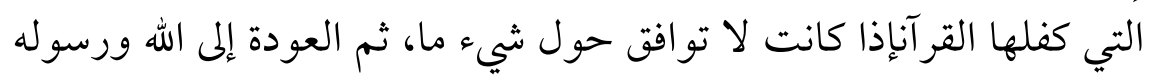

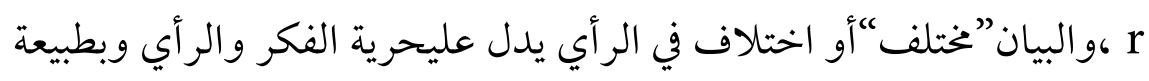

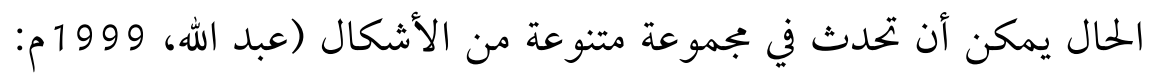

وواضح أن المساواة هي تتمثل فيها تجليات العلاقة بين المسلمين

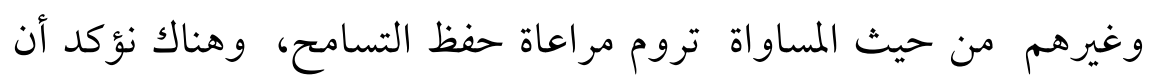

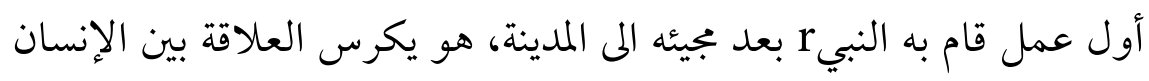


فى المجتمع الجديد، وهى علاقة أخوة، فلا سادة وعبيد، ولا أشرف وسوقة،

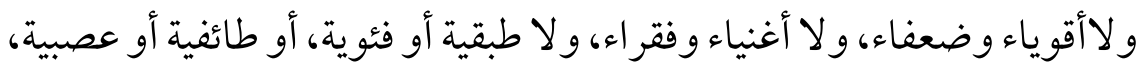
بل الجميع إخوة الدين والعقيدة. (المطيري، 20092: 147 ) اذن، فهذا نص صريح على أن المساواة تراعي التسامح والتعايش السلمي بينا و غير المسلمين.

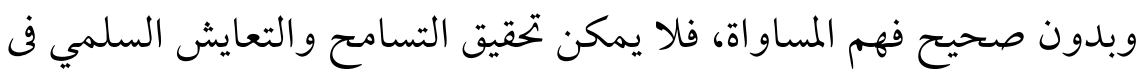
المجتمع التعددي.

فعلى المستوى العلمي يبدو أنه من الصحيح فعلا أن حفظ التسامح قد

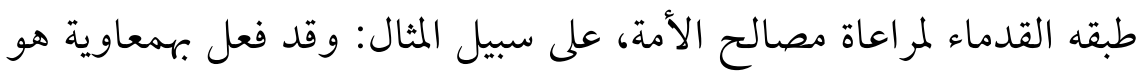

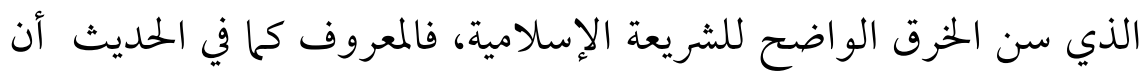
الكافر والمسلم لايتوارثان، لكن معاوية جعل المسلم يرث الكافر لا العكس الحس

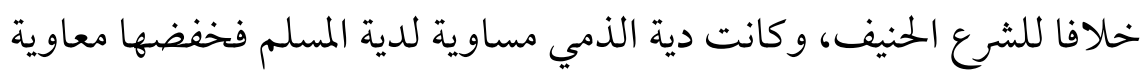

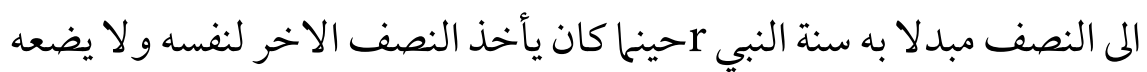
في بيت المال، وكذا رفض معاوية القصاص من ولاته الذين كانوا يقطعون

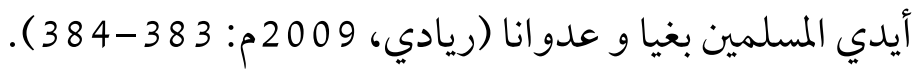
وقد يكون من المفيد هنا أن نشير الم أن حفظ التسامح في اطار أقليات المسلمين رخصة لتنفيذ الأحكام الشرعية لأنهم يعيشون في بلدان غير المسلمين، تختلف عن تلك البلدان ذات أغلبية المسلمين،وذلك يدل على نزول المثل الأعلى

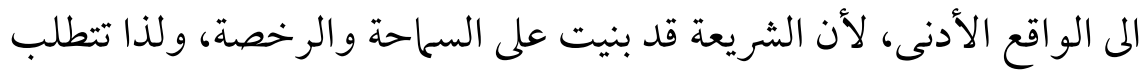

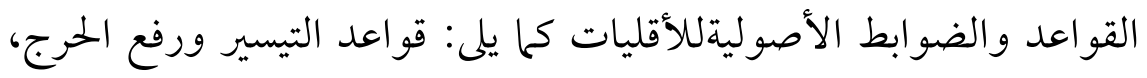
وقواعد تغير الفتوى بتغير الزمان، و قواعد تنزيل الحاجة منزلة الضرورة، وقواعد العرف، و قواعد النظر في المائلات، وقواعد قيام جماعات المسلمين مقام القاضى (بايح، 2009م: 170 ) ). والحت أن الفكر التطرفي مضاد للاسلام في هذا الاطار اذ أن أدلة التسامح من القر ان و السنة قد كثرت نصو صه صر احة أو غير صر احة، وذلك يدل على أن 
حفظ التسامح في الدين قطعي لإنه راجع الى كليات الشريعة، كما قال الشاطبي:

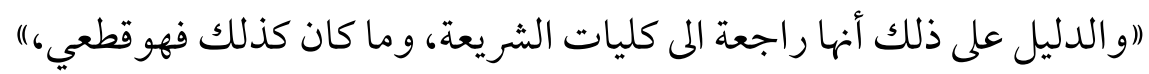

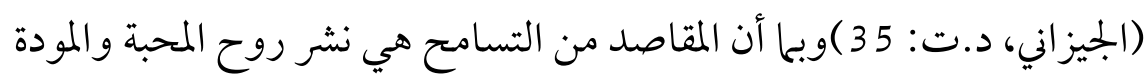

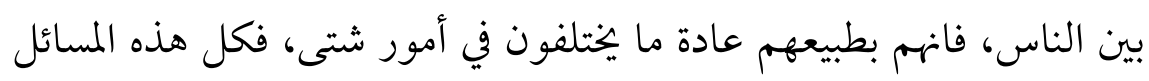

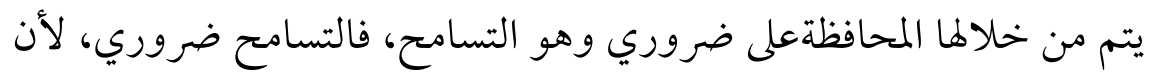

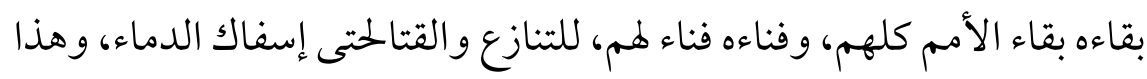

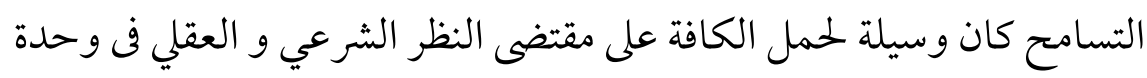

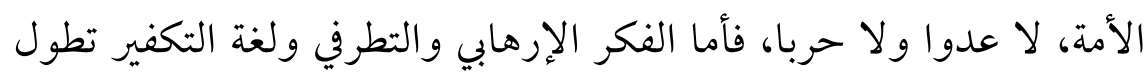

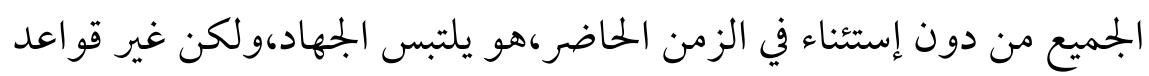
الإسلام، وبها يعارض تعاليمه السمحة.

ثانيا: نطاق دراستها الشاملة على العقيدة، والفقه والتصوف حتى يتسنى للقارئ الإحاطة بالشريعة علما وعملا، فلا بد من توضيح

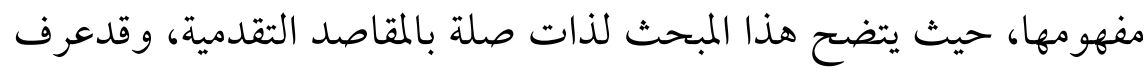
القرطبي أن الشريعة هى دين وضعه الله للعبد يتكون من الأحكام والنظام.

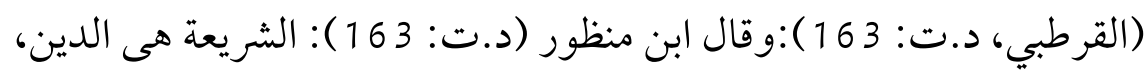

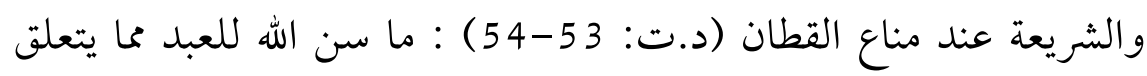

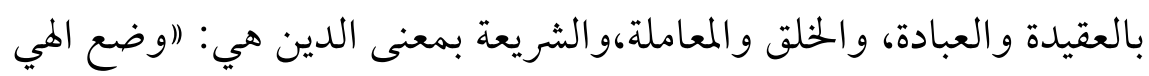

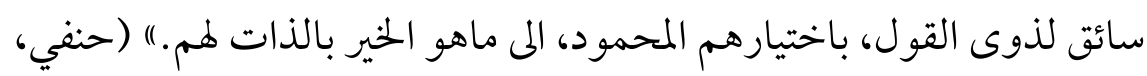

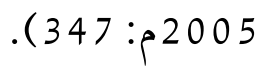

وانطلاقا من هذه التعريفات، فالشريعة تطلق على معنى واسع وهي

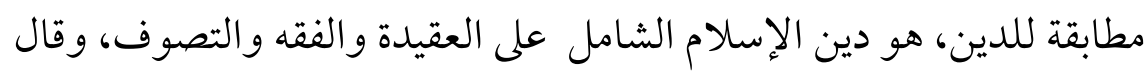

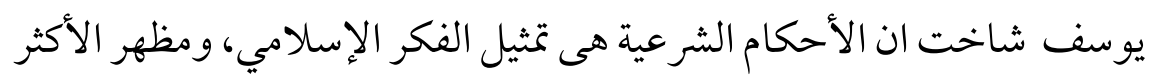


شيوعامن وجهة النظر العالمية للإسلام، وجوهر الإسلام نفسه، وأما الفقهيظهر

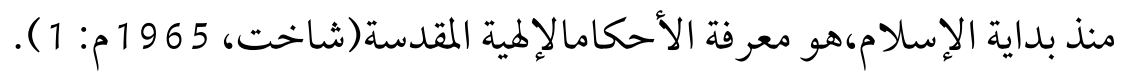
ولذا أن مصطلح الشريعة بمعنى الأحكام العملية دون الاعتقادات والتصوف، هو الغالب لدى الفقهاء، ومن هنا شاع التقابل بينها، حسبها

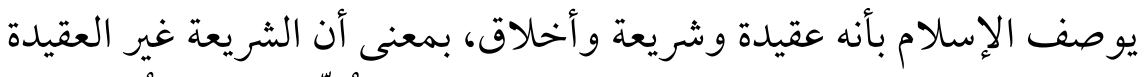

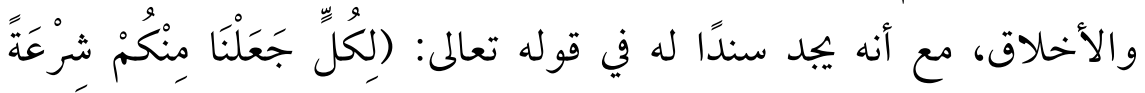

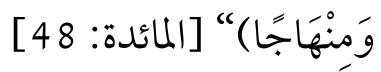

و الدين بمعنى الأحكام المشرو وعة يعتبر مصلحة للجماعة والأفر اد، لإن

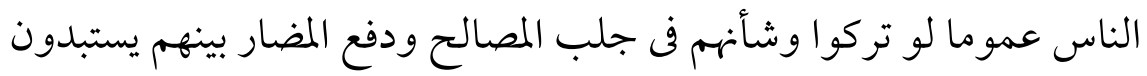

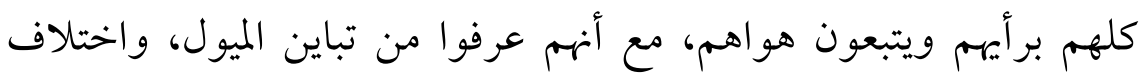

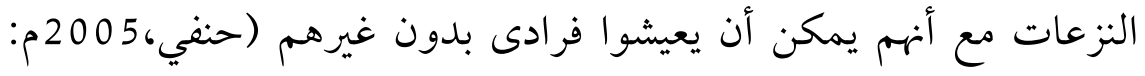

و الفكر الإرهابى منطق لايمت الى أي دين بصلة، ولسده الفكر الإرهابى،

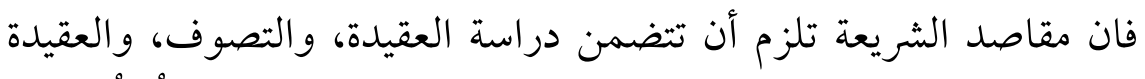

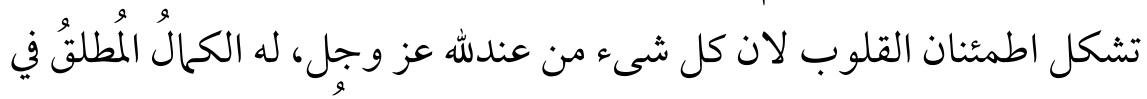

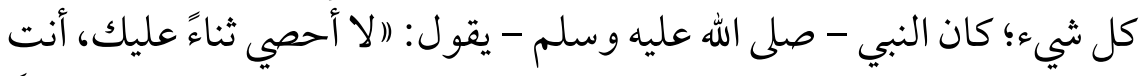

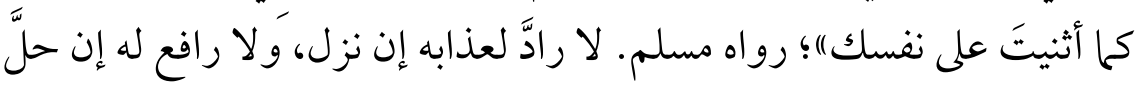

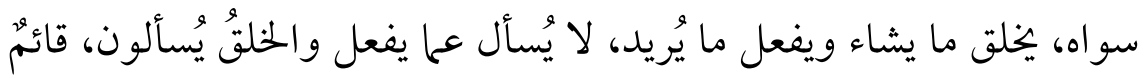

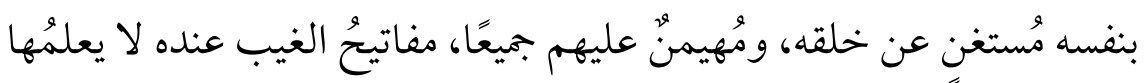

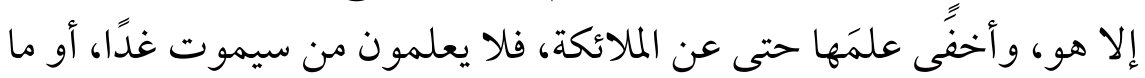

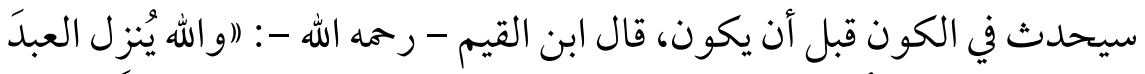

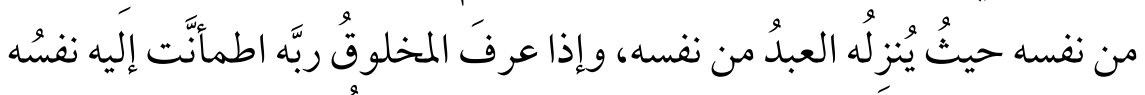

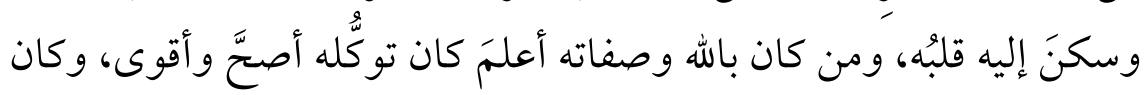

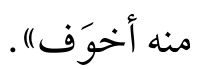


ويرتبط بهذا أن الفكرالإرهابى صادر عن المرجعية الأيدولوجية اما

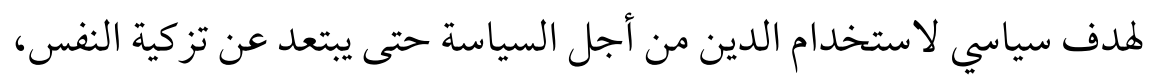

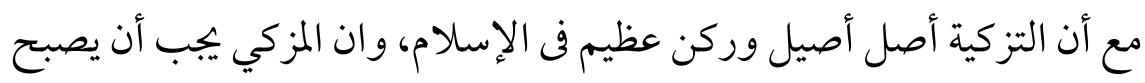

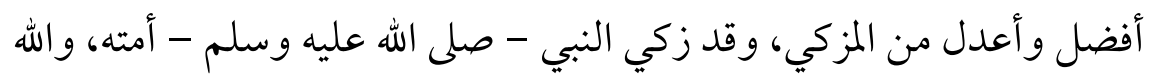

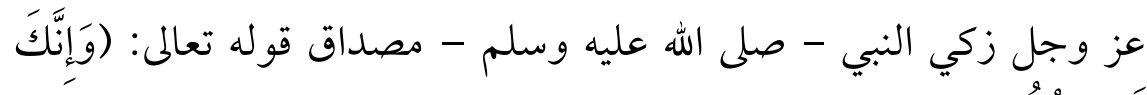

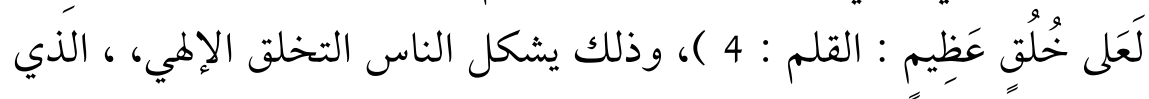

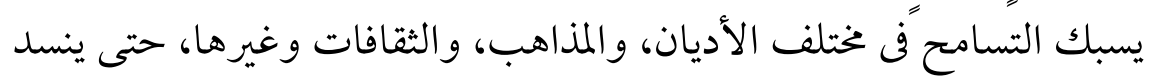
الفكر التطرفي والإرهابي، وذلك من أهم مايساعد فهم المقاصد التقدمية فها صحيحا.

والمطلوب راهنا: في مواجهة المتطرفين، علينا أن نحرر مضامين

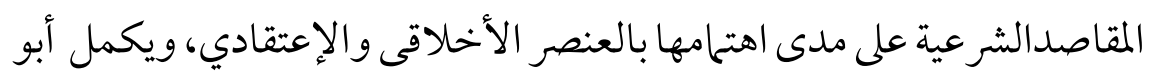

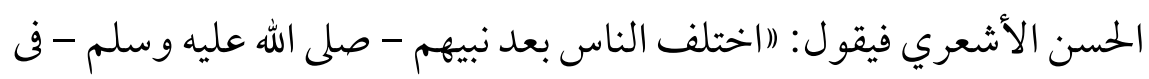

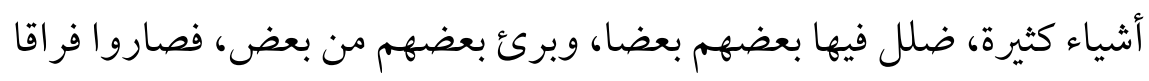

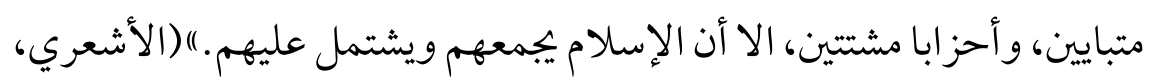
د.ت: د-1-1) (1)

وهذا نص جدير بأن يضعه الإرهابييون نصب أعيونهم، وهم ينظرون

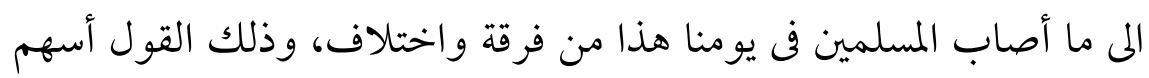

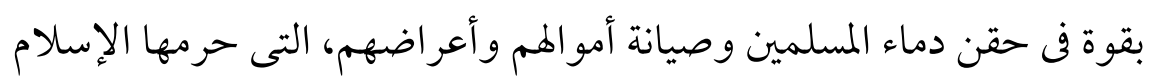

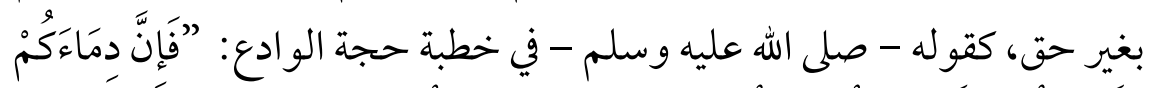

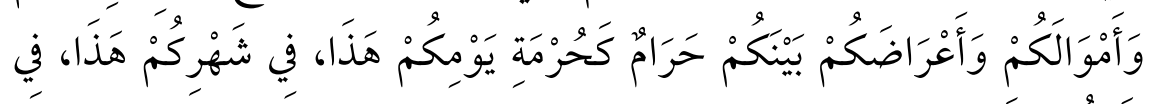

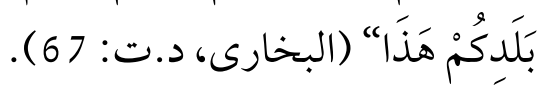

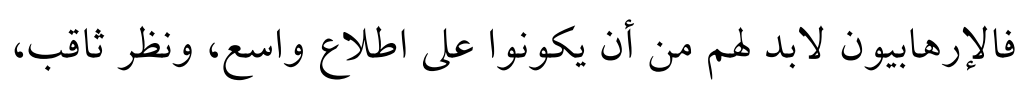

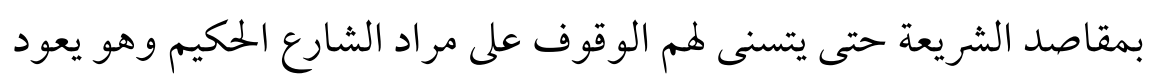

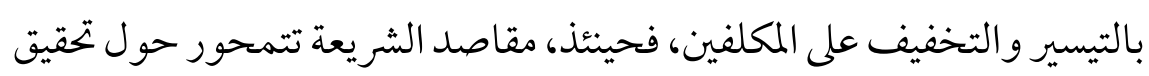


هدف واحد، وهو مصلحة العباد في العاجل والاجل،وقال الإمام الجويني:

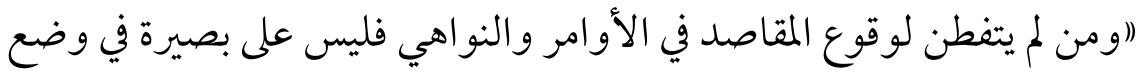
الشريعة.) (الجوينى، د.ت: 206 20ن ).

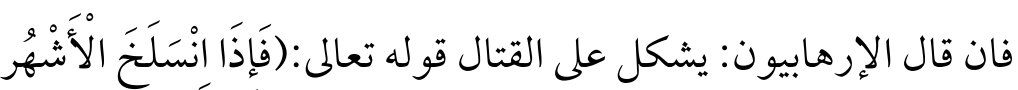

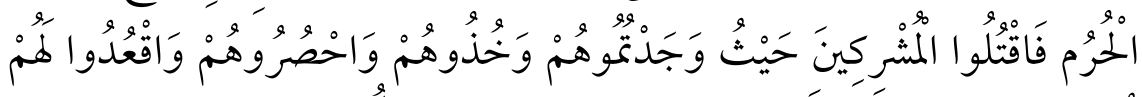

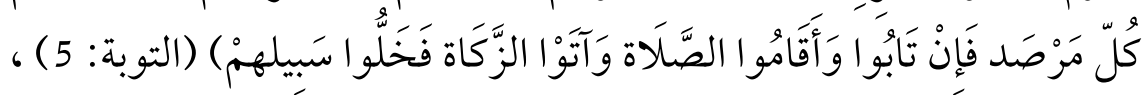

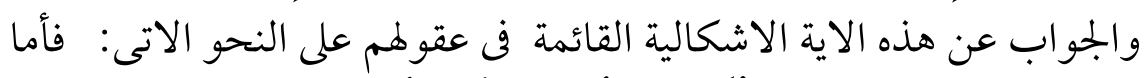

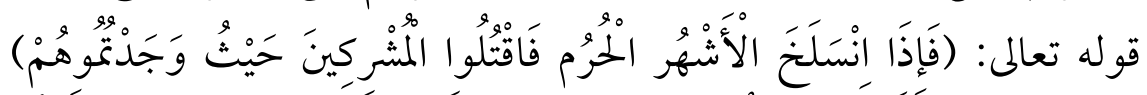

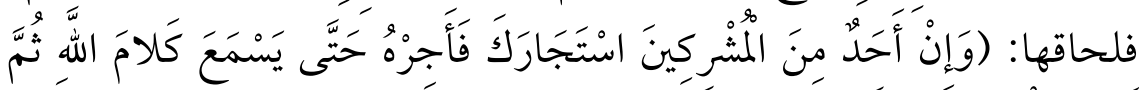

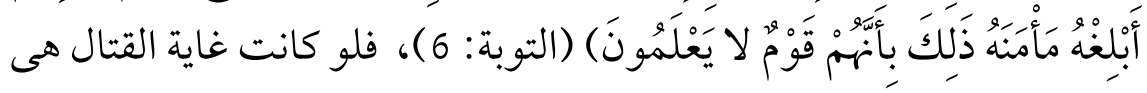

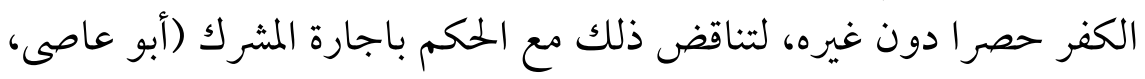
. (97-96: 2014

ومما هو جدير بالذكر أن الحروب الإسلامية لها دساتير سبق بها

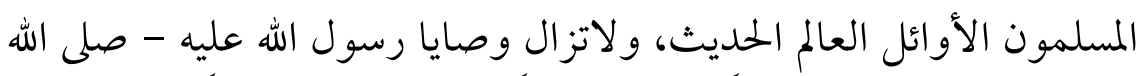

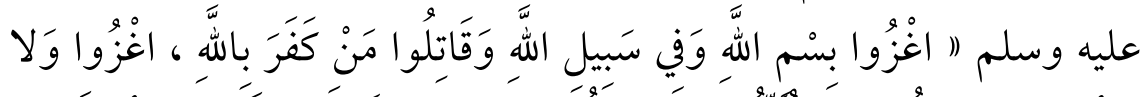

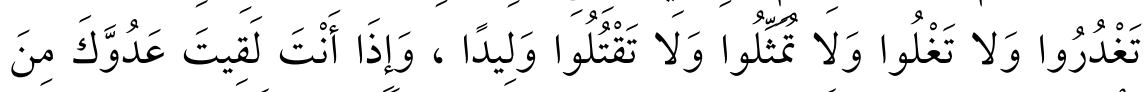

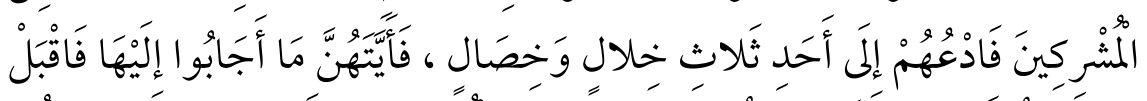

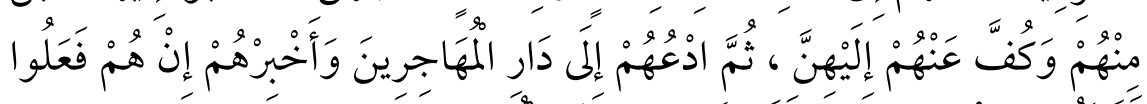

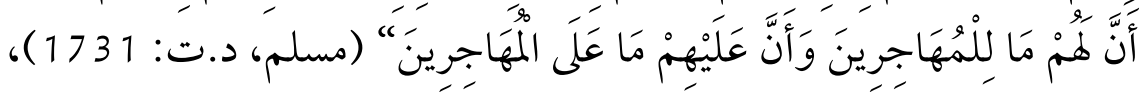

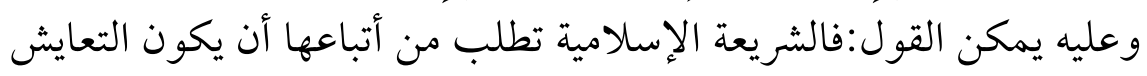

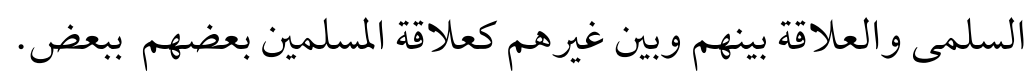

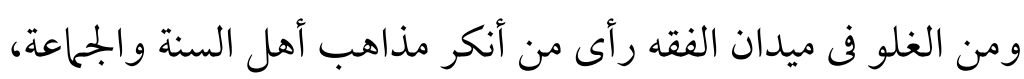

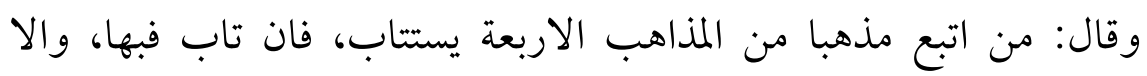

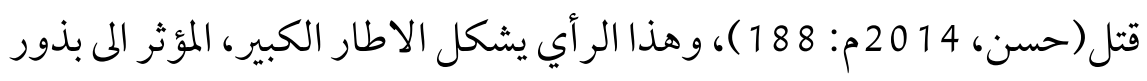


التطرف والإرهاب، اذن تحديات ومخاطر المتطرفين من كل جانب، ولابد له من

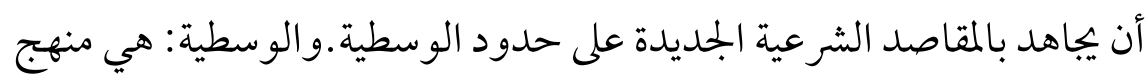

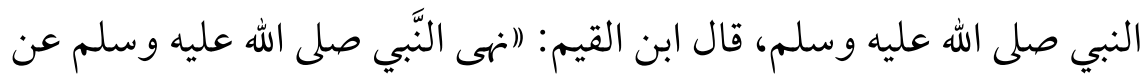

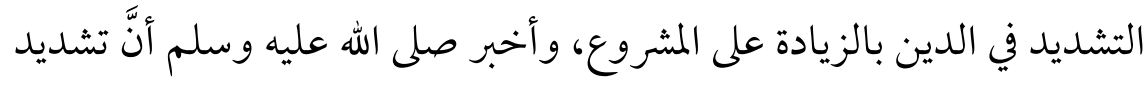

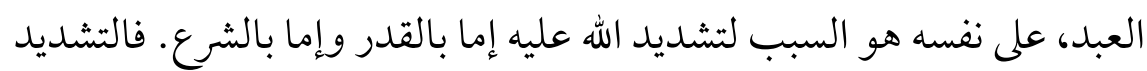

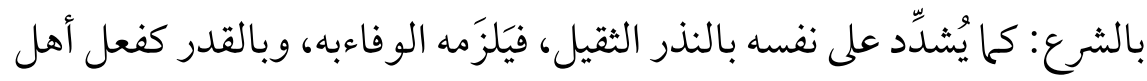

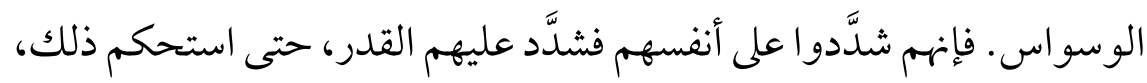

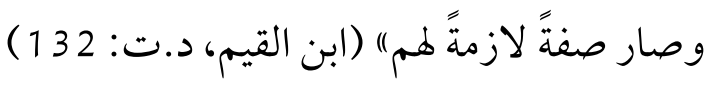

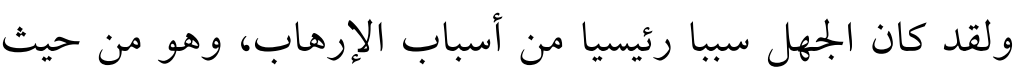

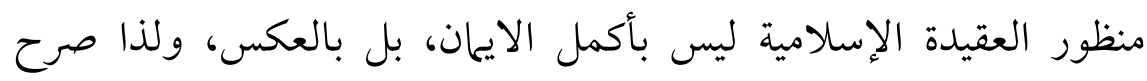

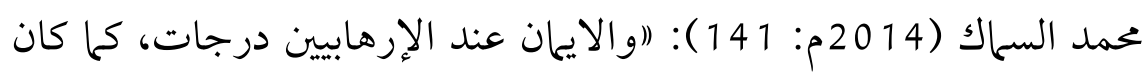

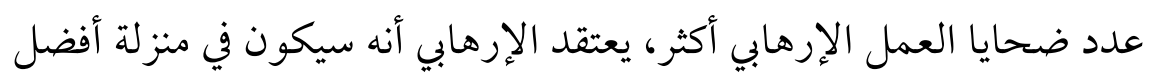

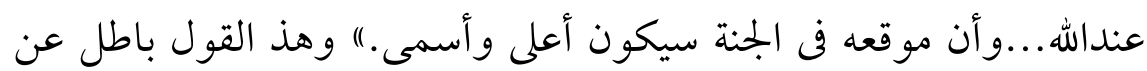

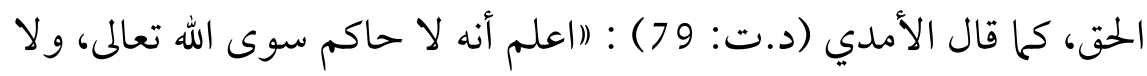

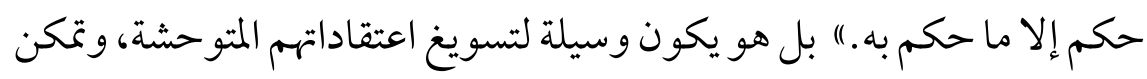

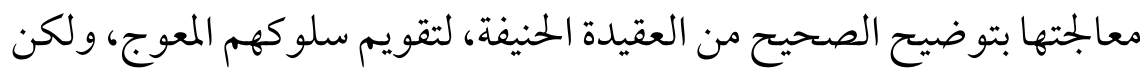
اعتقاداتهم مختلفة تماما، عصية على المعالجة.

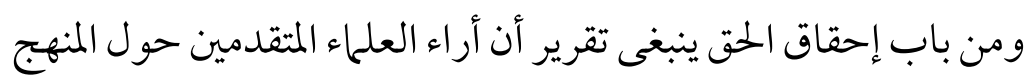
الإعتقادي متوسطة، وفى كتب العقائد نصوص عديدة تؤكد هذا المعنى، ومنها:

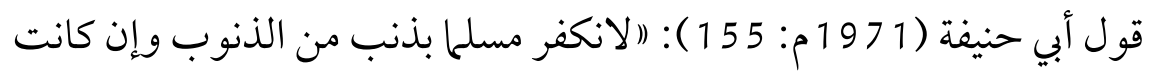

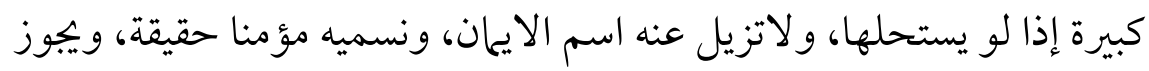

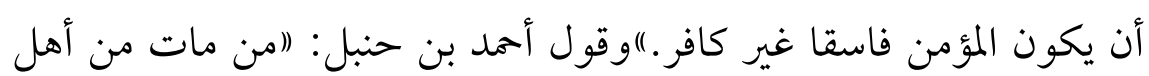
القبلة مو حدا يصلى عليه ويستغفر له، ولاتترك الصلاة عليه لذنب أنس أذنبه صغيرا

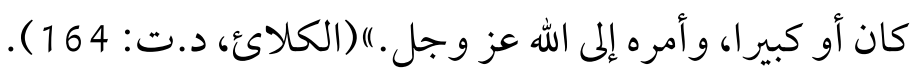


وليس من المبالغة قولنا ان الفكرالإرهابى تجسد في الغلو

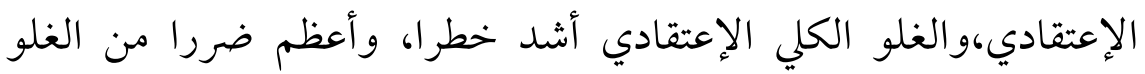

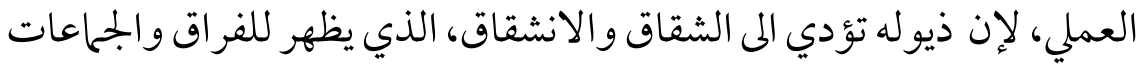

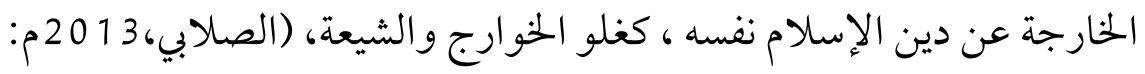

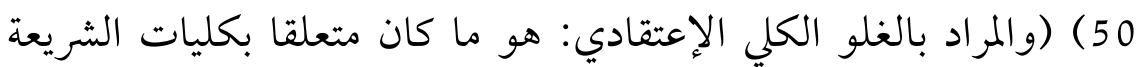

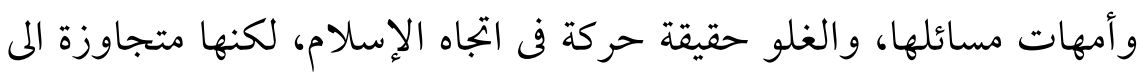

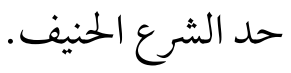

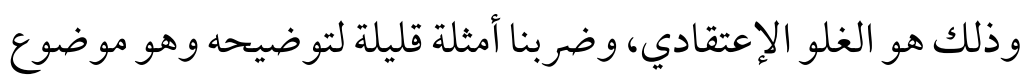

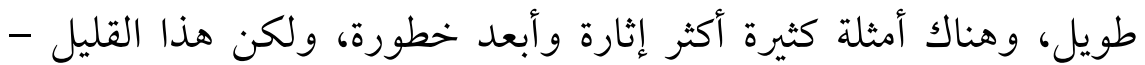

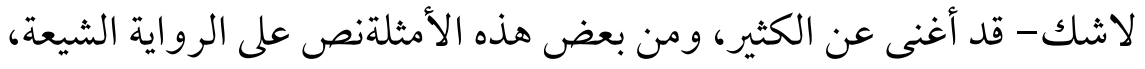

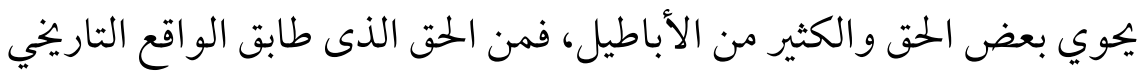

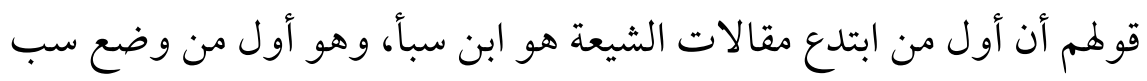

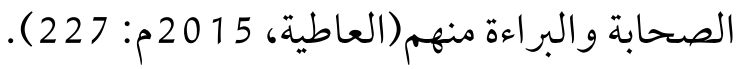
وبالإضافة الى المدخل الفتهى والإعتقادي، كانت مقاصد الشريعة

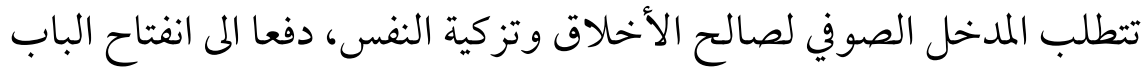

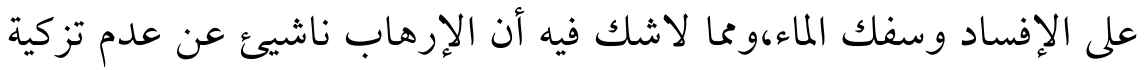

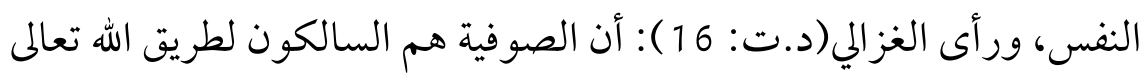

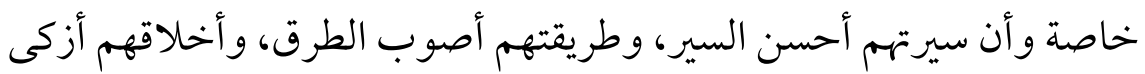

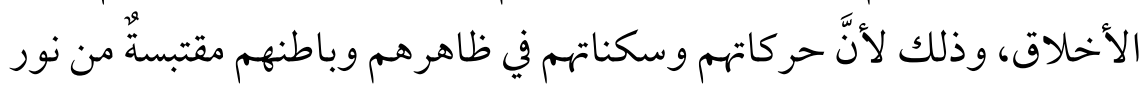

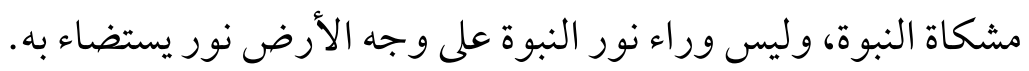

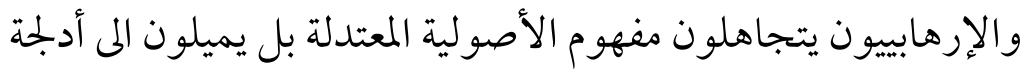

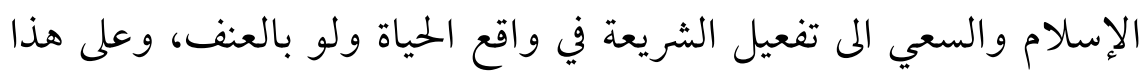

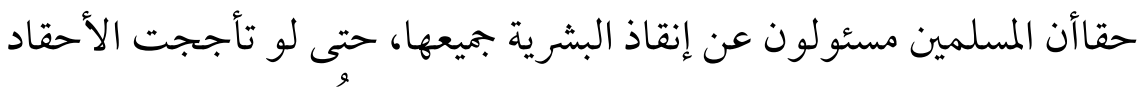

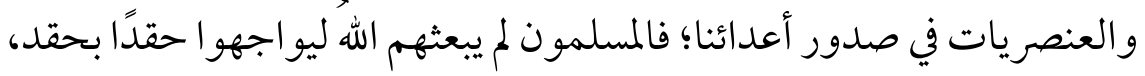




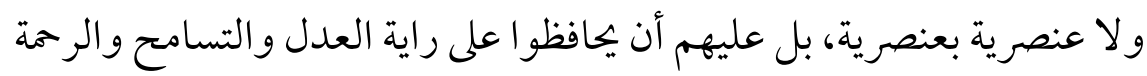

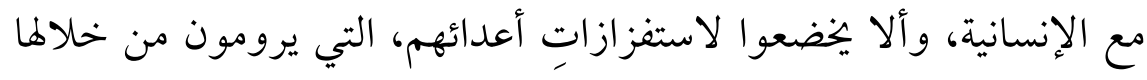

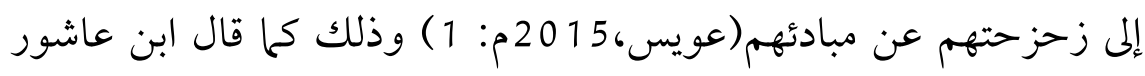

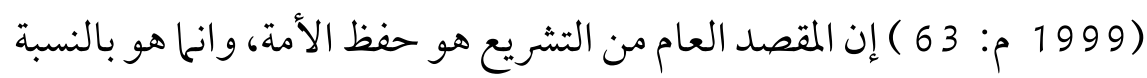

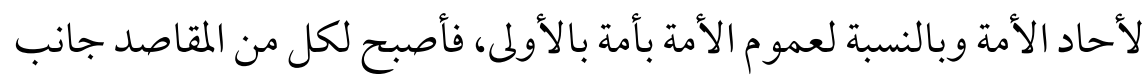
خاص بالأفر ادو وجانب خاص بعموم الأمة.

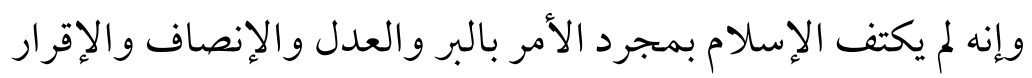

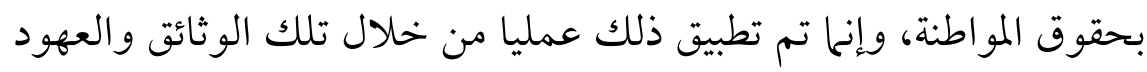

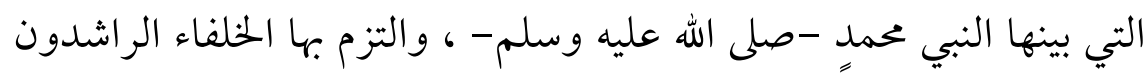

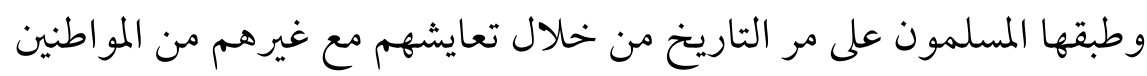

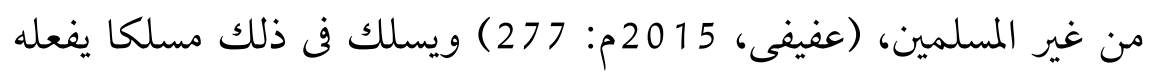

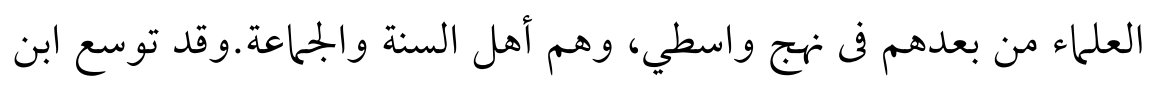

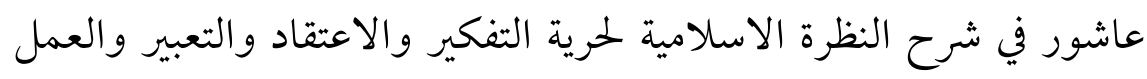

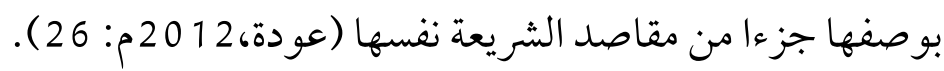
والمقاصد بهذا النوع هى التي تلحظ في جميع أحوال التشريع أو معظمها،

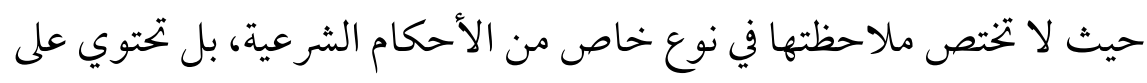

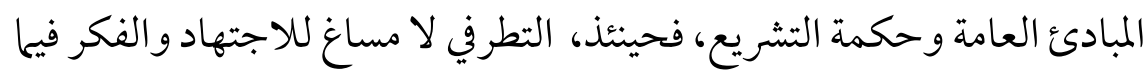

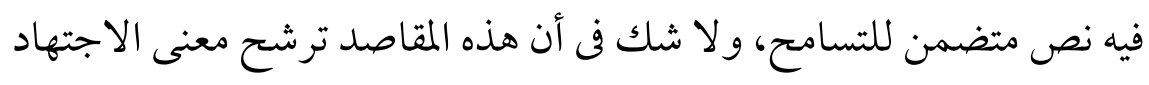

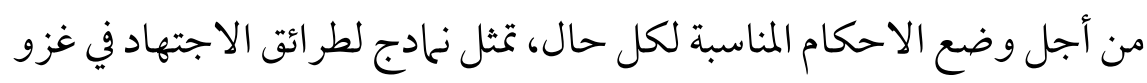

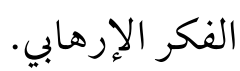

ولعله من الصحيح فعلا، نقول أن هذه المقاصد تتلاحق على منهج

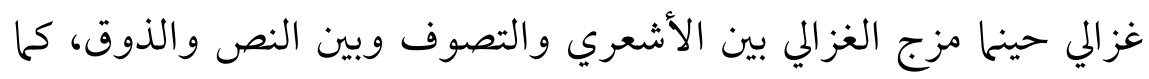

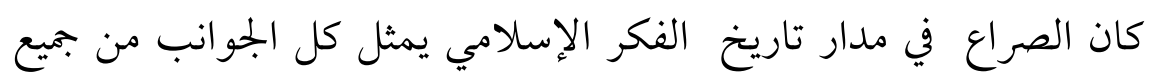

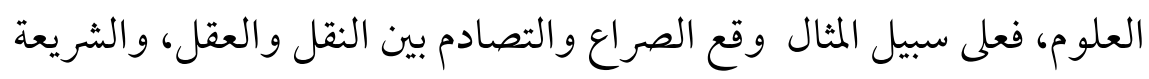


و السلوك، والظاهر والباطن، ومدرسة الرأي ومدرسة الحديث وهلم جرا،

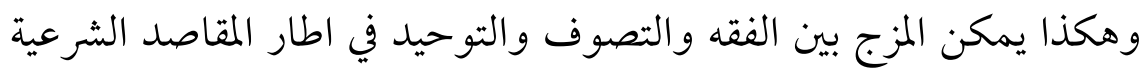

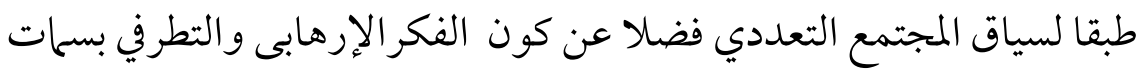
الإسلامدون أي توسط حقيقي بل بمدخل المقاصد الشرعية.

\section{ثالثا: تقديم أولويات الأدلة الكلية على الأدلة الجزئية}

وبقى شيىء أخر مهم في الو اقع أن الفكر الإرهابى يجنح الي نحو العنف

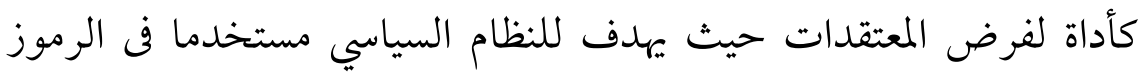

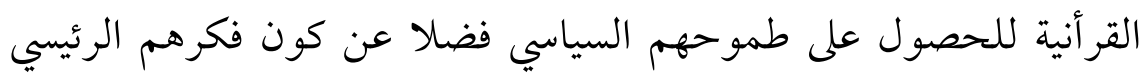

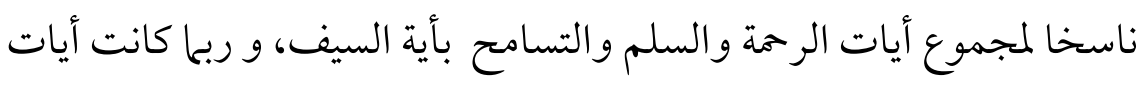
الرحمة كلية وأية السيف جزئية وفي الغالب أنالجزئية مقدمة على الكلية.

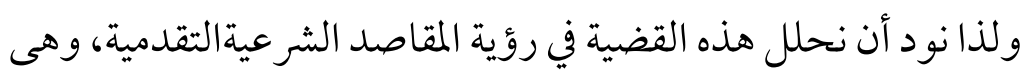

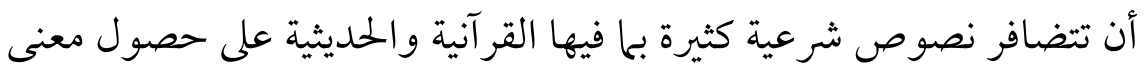

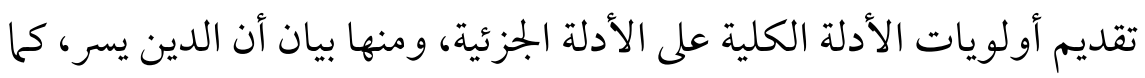

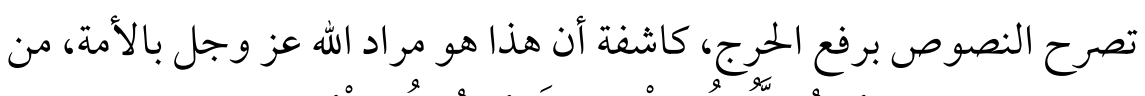

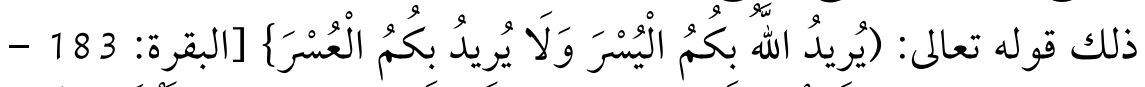

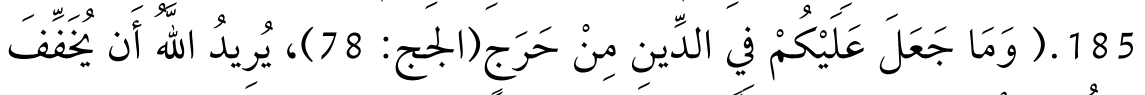

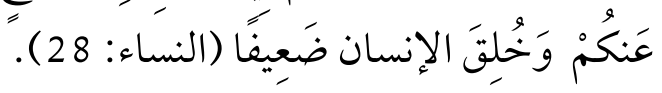

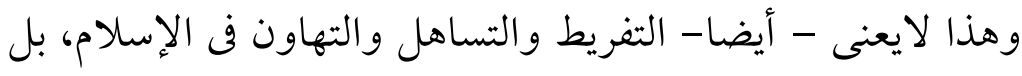

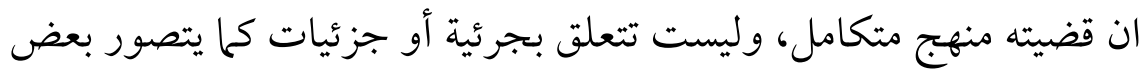

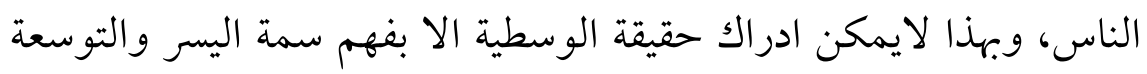

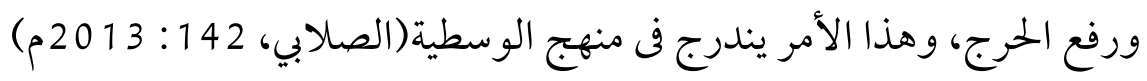

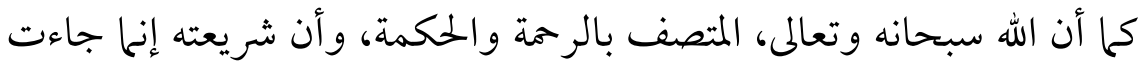

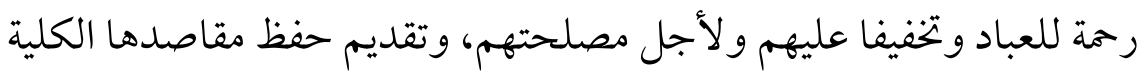




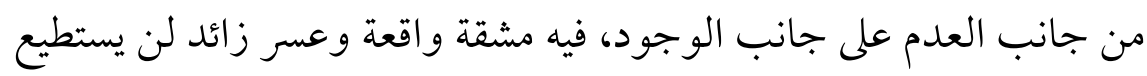

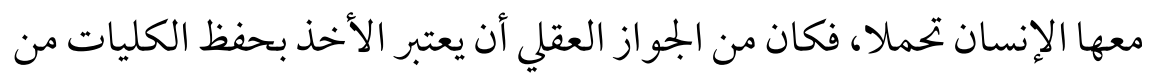

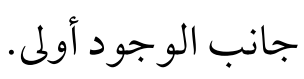

وقد كثرت أيات القرأن، الدالة على المبادئ العامة ومنها اختلاف

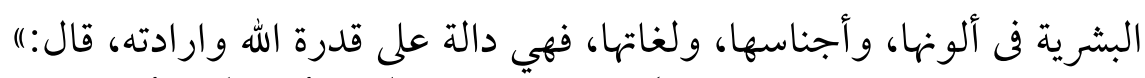

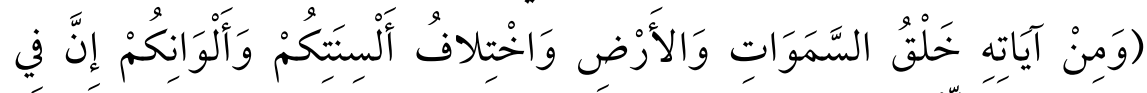

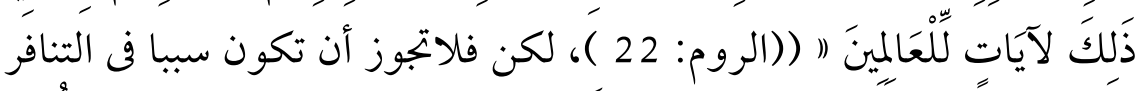

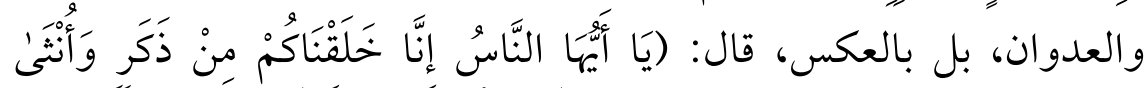

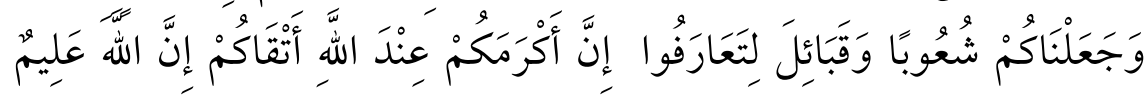

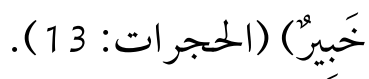

وتشدد الإرهابيون أيضا في حملتهم الفكرية المعادية على ما يبدو

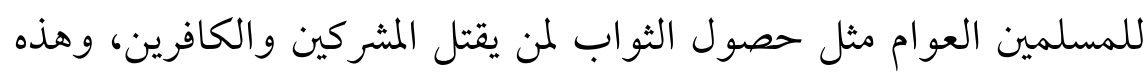

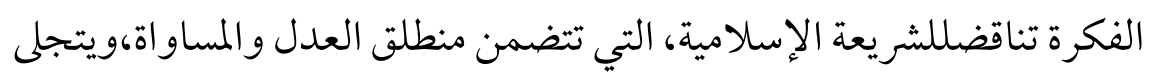

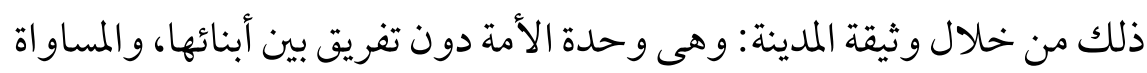

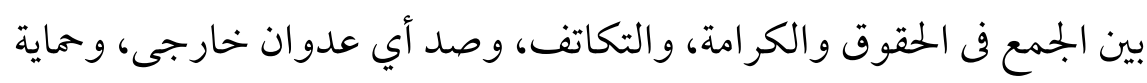

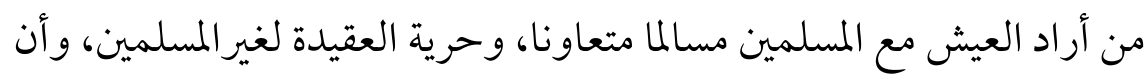

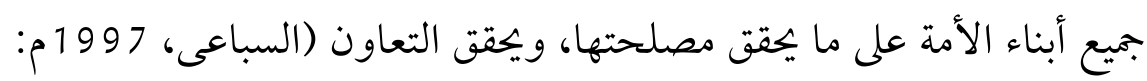

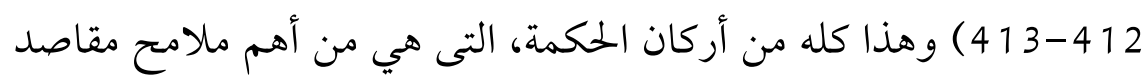
الشريعة التقدمية.

ولا يمكن توليد فكر الإرهابات عنهم إن فهموا المبادئ والقيم المرعية

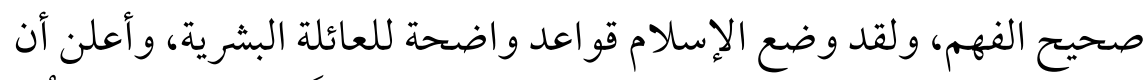

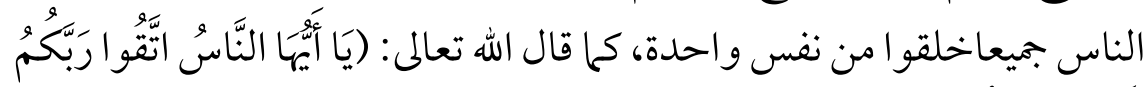

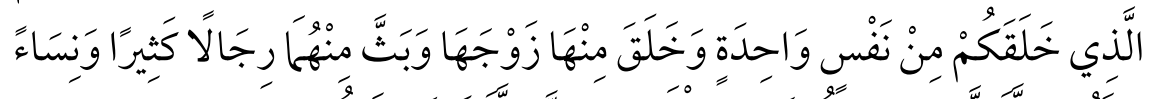

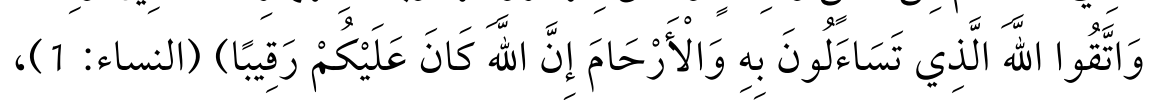


هذه الأية تفيد بقواعدها ملامح الوسطية للعناية بالأخوة البشرية في المجتمع

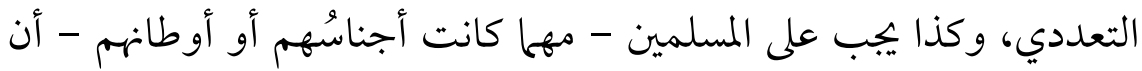

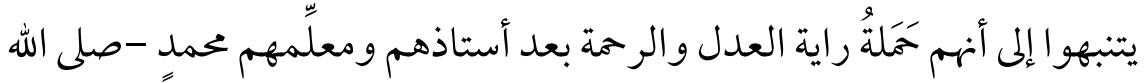
عليه وسلم - وعليهم أن يتنبهوا إلى أن الأمانةَ التي ائتمنهم الله عليها - وهي لهي

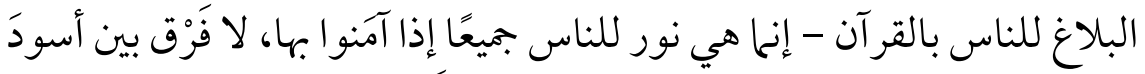

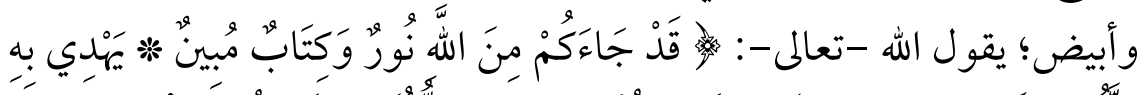

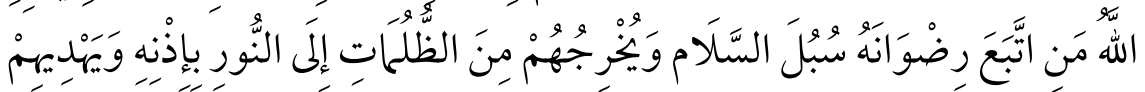

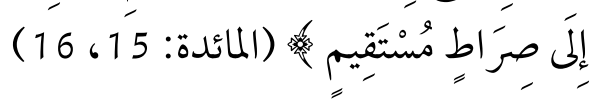
ولعل صيغ هذه المقاصد هي مخالفةللأراء الأغلبية السائدة من العلماء المتقدمين،لكن من حيث المبدأ لا تتعارض عن جوهر الشريعة الإسلامية،لأن الأراء لاتنتهي على كمر الدهوروفقا للتطورات والتغيرات، كما قال ابراهيم الباجوري من شرذمة الشافعية: (لوكان الشافعى حيا لافتى بهه) (الباجوري،

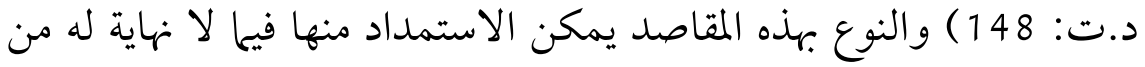
الحوادث والمشاكل التي تتكاثر على مرور العصور، مما ليس له حكم خاص به فضلا لرد الفكر الإرهابي و التطرفي.

عموما، إن الأدلة الكلية وأمثالها من النصوص الشرعية ترسم منهج

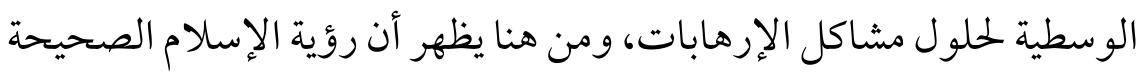

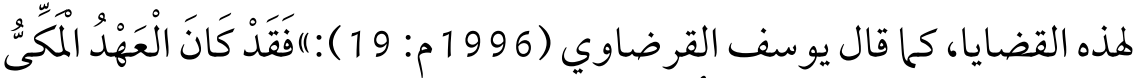

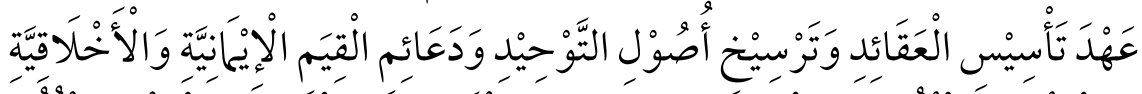

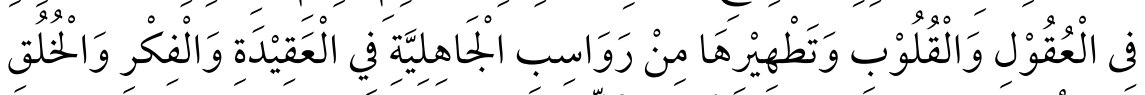

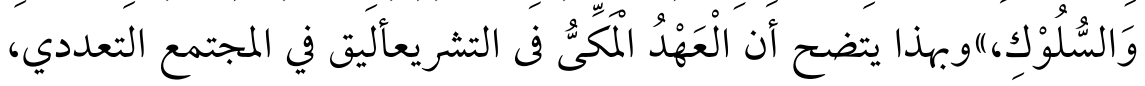
ولايمكن أن يتحقق ذلك الا بمر اعاة على منهج الوسطية بين التسهيل والتشدد، جلبا للمصالح ودرءا للمفاسد وهو من ملامح المقاصد التقدمية، كما قال الله 


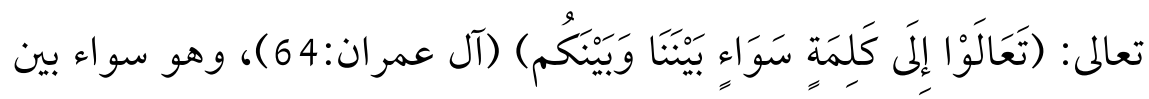

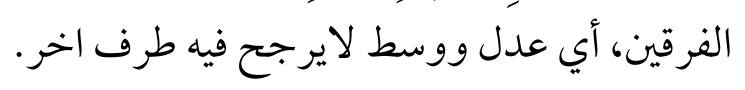

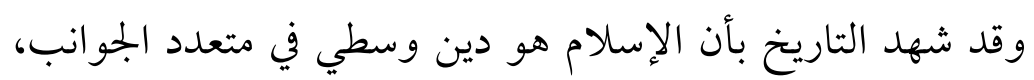

كما رأى رشيد رضا (د.ت:

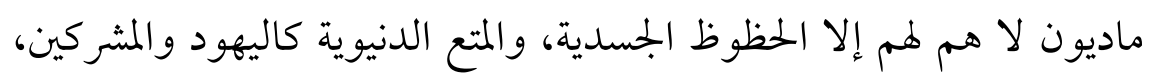

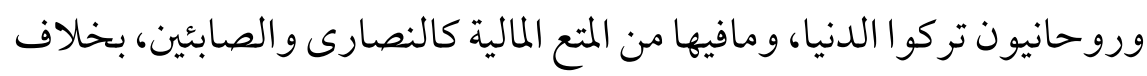

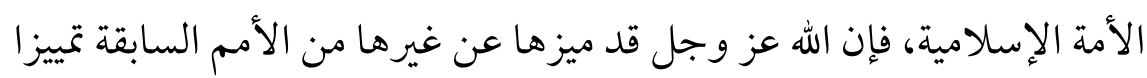

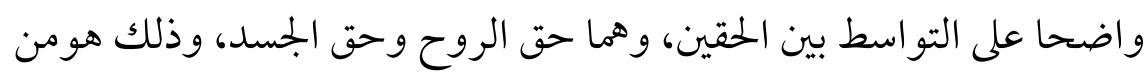

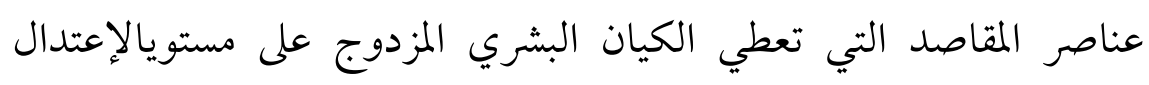

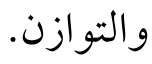

طبعا، فالعدل من الأسس والقيم التي جاءت بها جميع الشرائع

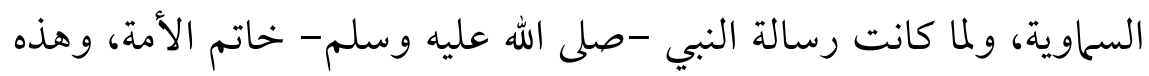

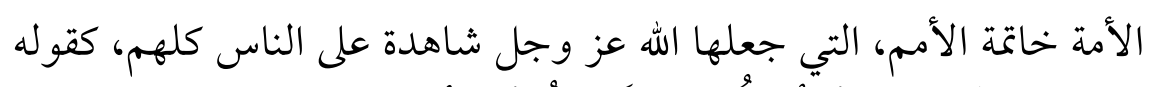

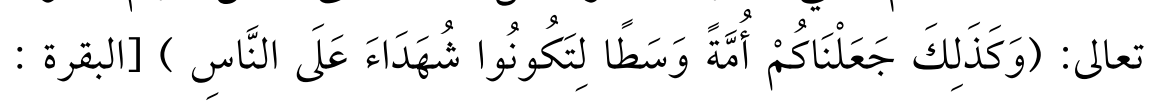

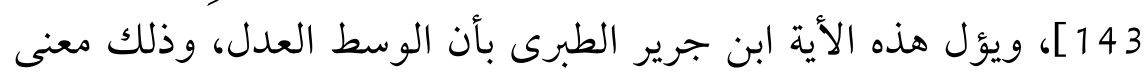

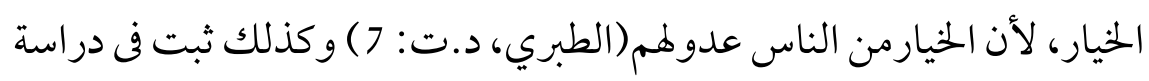

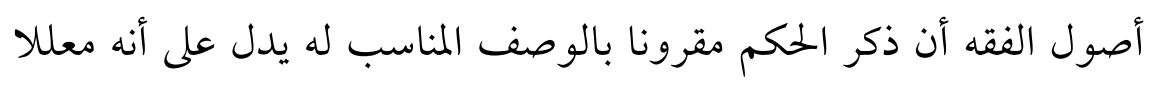

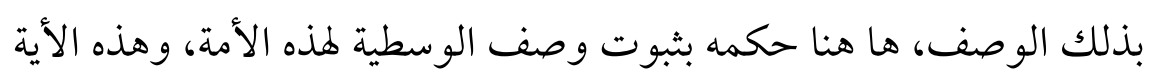

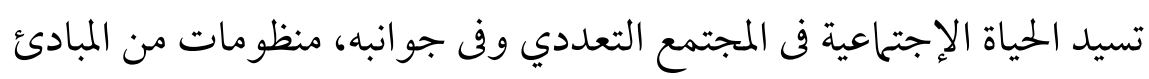

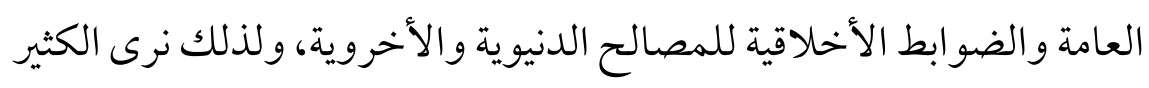
من سمات الإرهاب منحرفا واضحا على نهج المقاصد الوسطية.

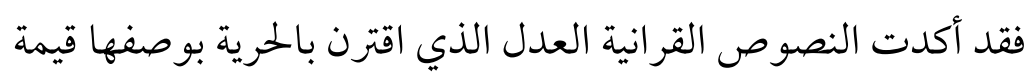
عليا لمصالح العباد، وقال ابن تيمية(د.ت:

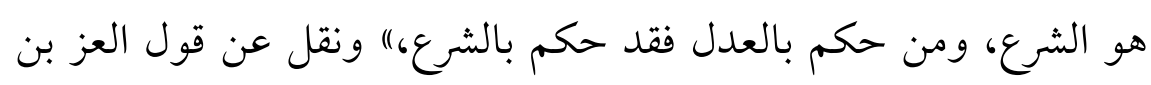


عبدالسلام: (ان العدل هو الأصل العام لجميع الأحكام الشرعية فى كل ميادين

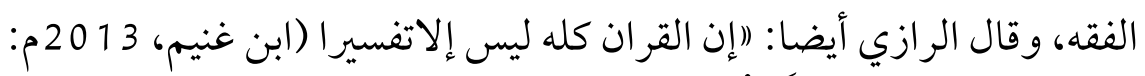

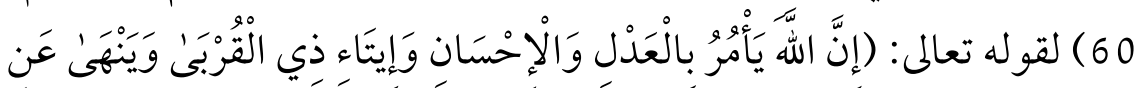

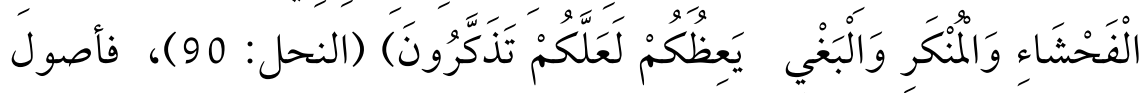

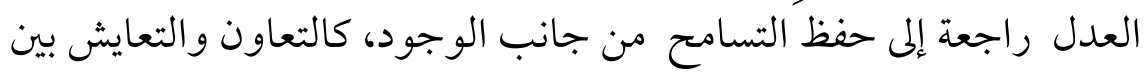

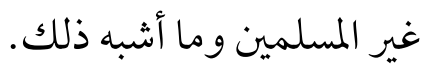

وحري بنا: من خلالمجموع تلك النصوص الشرعية، فان تقديم

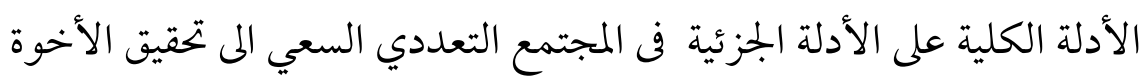

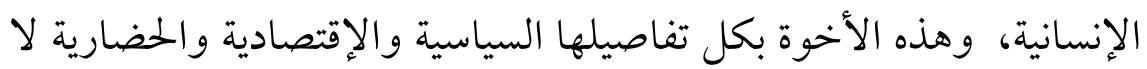

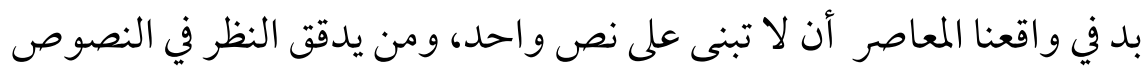

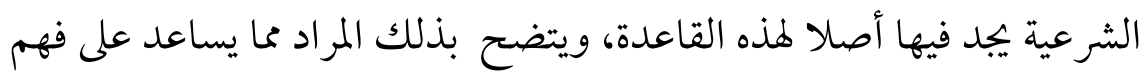

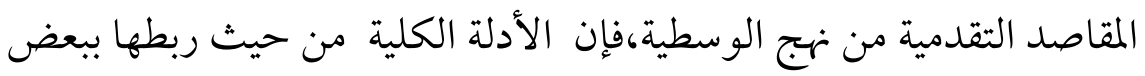

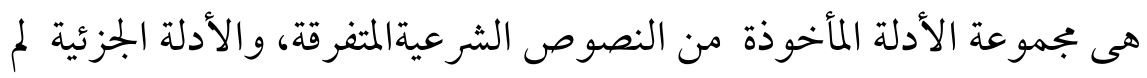

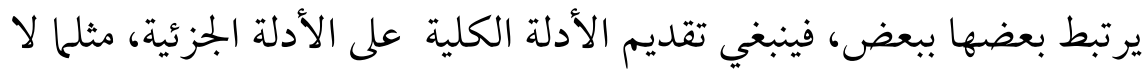

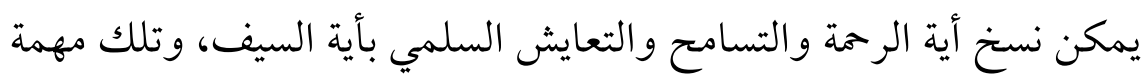

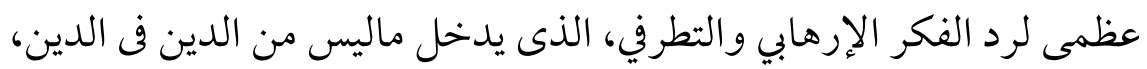

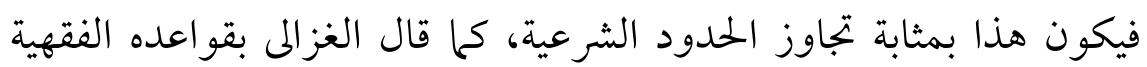

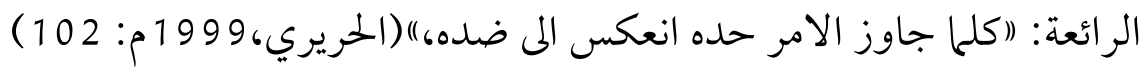
واذا، فكان ثمة خلاف واسع بين فكرة الإرهابات و المقاصد التقدمية. وهذا ما يضمن استمرار عملية الاجتهاد من أجل توليد الأحكام

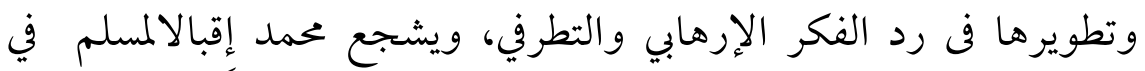

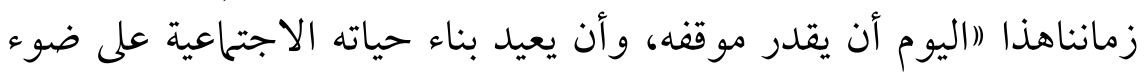

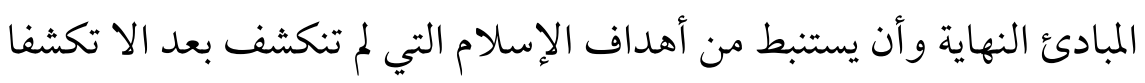


جزئيا.)( (اقبال، 2000 20: 13 2) ولهذا كان المجتهد بهذه المقاصد يستنبطالأحكام الشرعية، التي تنكشف كليا وشموليا لا تتجزأ.

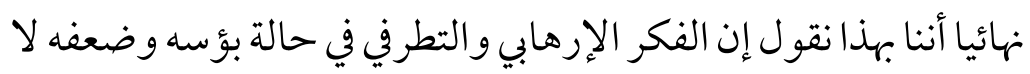

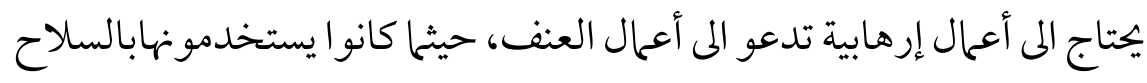

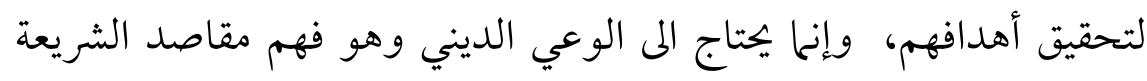

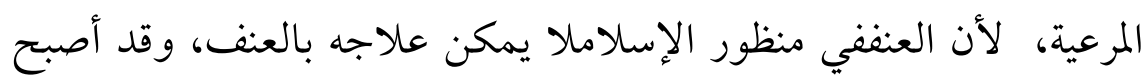

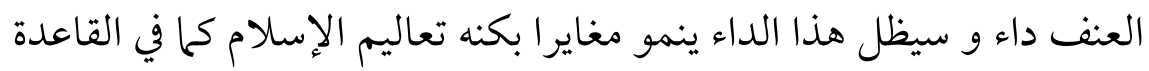

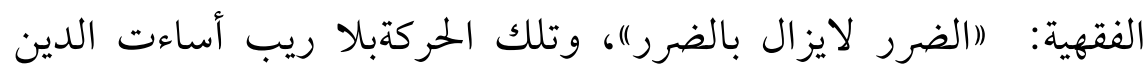

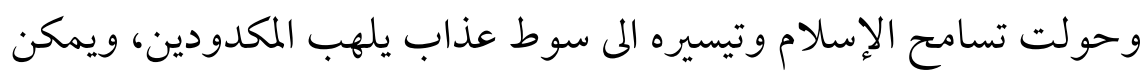

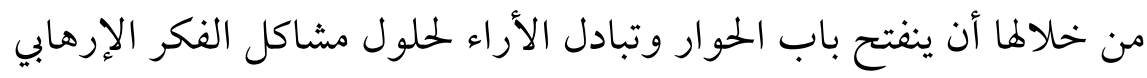
والتطر في بمدخل المقاصد التقدمية.

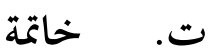

من أهم النتائج التي توصلت لها في هذا البحث أن الفكر الإرهابي

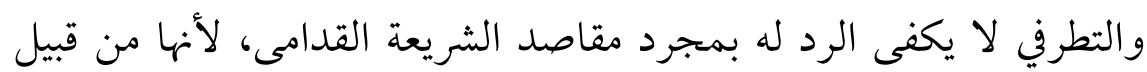

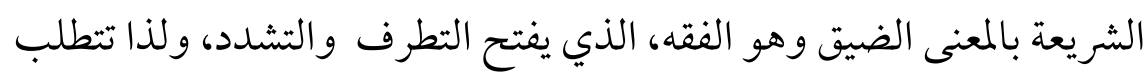

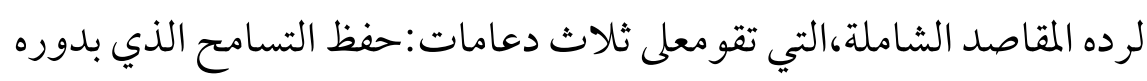

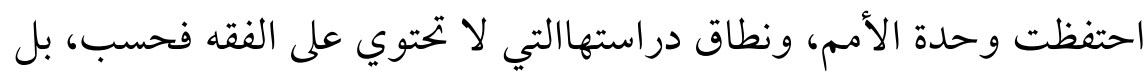

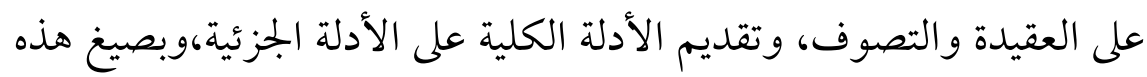

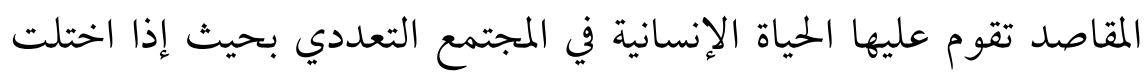
واحدة منها، فرجت الفكر الإرهابي والتطرفي. 


\section{المراجع}

Joseph Schacht، 1965، Introduction to Islamic law، London: Oxford University Press.

Masykuri Abdillah، 1999، Demokrasi di Persimpangan Makna، Yogya: PT. Tiara Wacana.

ابراهيم الباجوري، د.ت، حاشية الباجوري على ابن القاسم الغزي، بيروت،

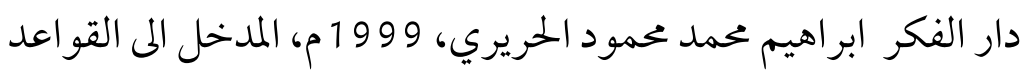

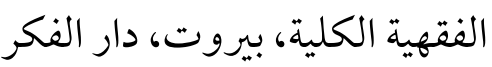

ابن القيم، د.ت، اعلام الموقعين عن رب العالمين، بيروت، دار الفكر

ابن القيم، د.ت، إغاثة اللهفان من مصائد الشيطان، بيروت، دار الفكر ابن تيمية، د.ت، بجموع الفتاوي، بيروت، دار الفكر ابن جرير الطبري، د.ت، جامع البيان عن تأويل آي القرآن، بيروت، دار الفكر

ابن خلدون، د.ت، المقدمة، بيروت، دار الفكر ابن عاشور، 1978 م، مقاصد الشريعة، تونس، الشركة التونسية ابن منظور، د.ت، لسان العرب، دار المعارف أبوحنيفة، 1997م، شرح الفقه الاكبر، تحقيق مروان الشعار، دار النفائس،

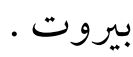

أحمد الريسوني، نظرية المقاصد عند الامام الشاطبي، المهد العالمي للفكر الإركا

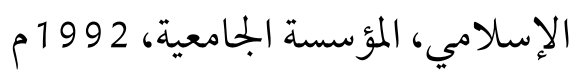


أحمد بن محمد الشرقاوي، 2015م، مقالة (اصور من سماحة الإسلام، أستاد التفسير وعلو القران المشارك بجامعة الأزهر

أحمد عبدالوهاب، 999 19، الحضارة الإسلامية وجهتها الله، والحضارة الغربية مركزها الإنسان، الناشر دار الصحيفة، القاهرة.

مسلم، فى صحيح مسلم، بيروت، دار الفكر الامام الأشعري، مقالات الإسلاميين، بيروت، دار الفكر الأمدي، د.ت، الإحكام في أصول الأحكام، بيروت، دار الفكر البخارى، د.ت، صحيح البخاري، دار ابن كثير، بيروت جاسر عودة، 2012م، مقاصد الشريعة دليل للمبتدئين، لندن، المعهد العالمي للفكر الاسلامي

حاكم المطيري، 2009م، تحرير الإنسان وتجريد الطغيان، بيروت، المؤسسة

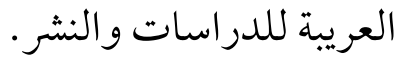

خالد محمد عبد الو احد حنفي، 14 20م، اجتهاد ات عمر بن الخطاب، بيروت، دار ابن حزم.

د. ابراهيم مذ كور، 1997م، فى الفلسفة الإسلامية منهجه وتطبيقه، بيروت،

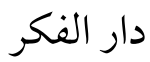

د. عبد الحليم عويس، 15 20م، (الرسالة التسامح والرحمة في الإسلام، ، الناشر

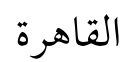

د. محمد جلال شرف : دراسات التصوف الإسلامى، بيروت، دار الفكر د. مصطفى السباعى، 7997 م، اشتراكية الإسلام، بيروت، دار الفكر د. مصطفى مفلوس، 2009م، التصوف فى الميزان، بيروت، دار الفكر 
داود ابن ماخلا، 2013م، عيون الحقائق، دار الكريم، القاهرة رضا حمدي،1620، الديموقرطية الروحية: مراجعة لمقالة (الاجتهاد)) عند اقبال، اسلامية المعرفة مجلة الفكر الإسلامي المعاصر . زكريا الأنصاري، د.ت، غاية الوصول، سمارنج، طه فوتر الشاطبي، د.ت، المو افقات في علم الاصول، بيروت، دار الفكر Program Pascasarjana-Lembaga Studi Agama dan Sosial IAIIN Surabaya، Volume 04، Number 026 December 2010 ، Journal of Indonesia Islamعبد الوهاب خلاف، 1986م، علم اصول الفقه، دار القلم، عبدالله بايح، 2009 2م، صناعة الفتاوى و فقه الاقليات، بيروت: دار المنهاج، عبدالله مبروك النجار، 140 في مواجهة الفكر الرهابي، الناشر القاهرة. عبدالملك الجوينى، د.ت، البرهان، دار الوفاء، المنصورة. عثمان بن غنيم، 13 20م، الظلم وانعكاسته على الإنسانية: رؤية شرعية، الدوحة، وزارة الاوقاف و الشئون الإسلامية.

عطا الله نجيب العايطة، 2015م، الفراق الإسلامية وموقف أهل السنة والجماعة منها، الأردن، دار الفاروق.

علال الفاسي، 200 20، مقاصد الشريعة الإسلامية ومكارمها، مكتبة الوحدة

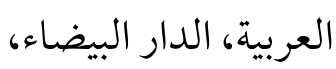


على محمد الصلابي، 2013م، الوسطية في القران الكريم، القاهرة، دار ابن الجوزي،

الغزالى، د.ت، المستصفى، دار المعرفة، بيروت. الغزالى، د.ت، المنقد من الضلال، القاهرة، مكتبة صبيح الغزالي، د.ت، مشكاة الأنوار، بيروت، دار الفكر

الكلائ، د.ت، شرح إعتقاد أهل السنة والجماعة، بيروت، دار الفكر محمد إقبال، 2000م، تجديد التفكير الديني في الإسلام، ترجمة: عباس محمود، القاهرة: دار الهداية للطباعة والتوزيع. محمد السماك، 2014م، في التطرف والإرهاب ، الناشر القاهرة. محمد بن حسين الجيزاني، د.ت، تهديب المو افقات، بيروت، دار الفكر محمد رشيد رضا، د.ت، تفسير المنار، بيروت، دار الفكر محمد سالم أبو عاصى، 14 2م، كلمة في فقه الجهاد، ، القاهرة، دار ابن الجوزي محي الدين عفيفى، 15 2م، المو اطنة والتعايش السلمى فى منظور الإسلام، مصطفى الشكعة، 2013م، اسلام بلامذهب، لبنان، دار المصدرية للبنانية، مناع القطان، د.ت، مباحث علوم القرأن، منشورات العصر الحديث، نعيم حسن، 2014م، دور العلماء والموسسات الدينية فى مواجهة الغلو

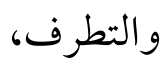
يوسف القرضاوي،6 199 م، فقه الصيام، مصر، دار الوفاء. 


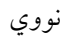

